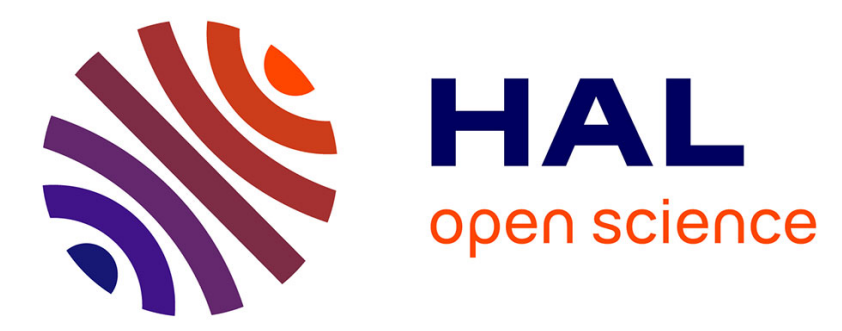

\title{
Culture of peace and the art of the war in Saharan rock art
}

Michel Barbaza

\section{To cite this version:}

Michel Barbaza. Culture of peace and the art of the war in Saharan rock art. Quaternary International, 2018, 491, pp.125-135. 10.1016/j.quaint.2016.09.062 . hal-01995264

\section{HAL Id: hal-01995264 \\ https://hal.science/hal-01995264}

Submitted on 15 Feb 2019

HAL is a multi-disciplinary open access archive for the deposit and dissemination of scientific research documents, whether they are published or not. The documents may come from teaching and research institutions in France or abroad, or from public or private research centers.
L'archive ouverte pluridisciplinaire HAL, est destinée au dépôt et à la diffusion de documents scientifiques de niveau recherche, publiés ou non, émanant des établissements d'enseignement et de recherche français ou étrangers, des laboratoires publics ou privés. 
1. Contexts and concepts

2. From survival instinct to the reign of pass. .

3. The ideal society

4. Staving off violence

5. The Bovidian: an ast of memory

References

Show full outline

Figures (19)
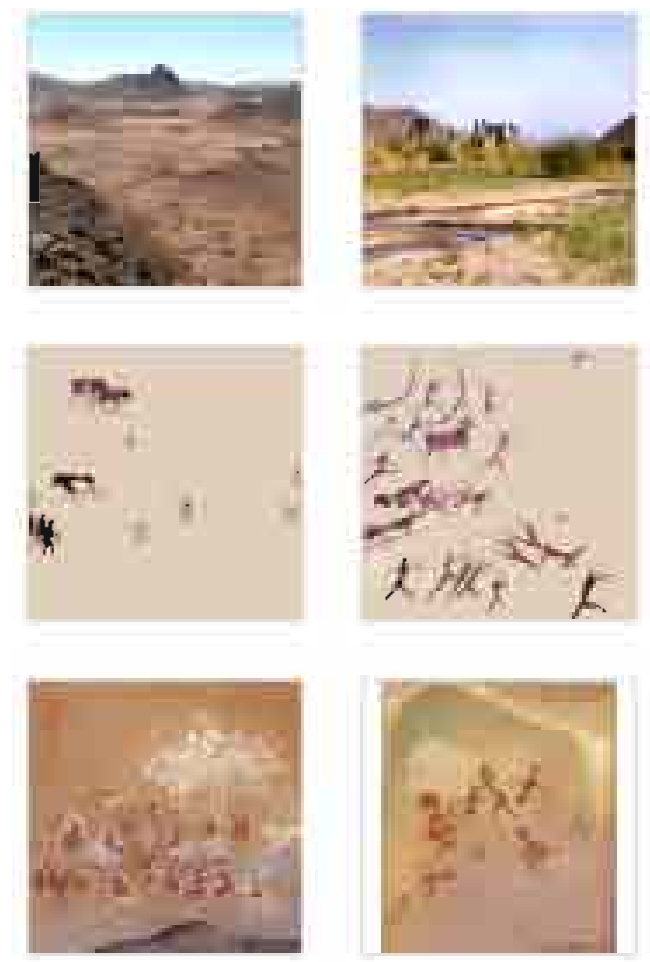

Show all figures

\section{Cultures of peace and the art of war in Saharan rock art}

Michel Barbaza

田 Show more

https://doi.org/10.1016/j.quaint.2016.09.062

Get rights and content

Based on the quality and abundance of its rock art, the Central Sahara constitutes a veritable open-air repository of extraordinary testimonies of the lives of Neolithic herders. How can we understand and interpret this rock art? Why the images? Why do the bovidian representations of daily life in the Saharan Neolithic with surprising realism give way to schematic images and cryptic imprints that express the existential uncertainties of "Round Head" societies confronted with a changing world?

In distinguishing the myth, substance of the collective unconscious, from the mythological stories that it generates, the present author brings forth in successive stages the underlying logic of these astonishing compositions. Drawing on the combined methods of prehistoric archaeology, art history, and sociocultural anthropology, I illustrate the principles for an anthropology of rock art. Finally, in placing these results in the context of the prehistoric Saharan ecology, I indicate the potential causes of tension and conflict among the groups of pastoral nomads.

Before aridity and desertification favored the emergence of a protohistoric society of merchants and warriors, the Bovidian groups established the conditions that allowed for the rise and maintenance of a grand pastoral civilization. The stories that captured the essence of this society are lost forever, but the mythological system that generated them remains fleetingly visible.

$<$ Previous article

Next article

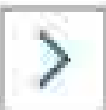

\section{Keywords}

Rock art; Sahara; Pastoralism; Bovidian; Anthropology; Myth 


\section{Contexts and concepts}

\subsection{The prehistoric Sahara}

Among the many functions attributed to rock art, the prophylactic role that it can play has been underemphasized. Saharan pastoral societies, confronted with the success of their socio-economic system and the effects of environmental degradation, established a discourse to regulate human relations in conformity with their values and systems of representation. For them, the primary aim was the avoidance of conflict, both between and within social groups. The archaeologist facing decorated panels today can see the effects of this process and consider it in terms of what remains observable.

In the central Sahara, in the context of the past four or five millennia preceding the widespread aridification that conditioned the current environment, the unique climatic conditions established with the onset of the Holocene allowed the large masses of air situated between the Gulf of Guinea and the North Atlantic to follow patterns of convective rainfall into the heart of the Saharan zone (Lem et al., 2016). The resulting rains transformed the "grand desert" of the Pleistocene into an immense expanse of savannahs and steppes, drained by powerful waterways and punctuated by countless lakes. Around 5000 years ago, the effects of accelerated deglaciation in the subarctic regions on atmospheric circulation re-established the high-pressure systems characteristic of the tropics. At first moderate and occurring in successive episodes of drought, the process of aridification affected populations dependent on an ecosystem that was, originally, eminently favorable to the development life in all its forms: plant, animal, and human (Petit-Maire, 2012). In the face of the success of this socio-economic system: "The influence of an increasingly arid environment surely led to an increasing competition among groups, over land rights and acces toresources. " (di Lernia, 1999, p. 18; di Lernia, 2006).

Though difficult to prove, based on a strong set of assumptions that rest on the discoveries from numerous and extensive archaeological sites along the shorelines of ancient Saharan lakes, it is possible to argue that this technological and environmental context generated a significant occupation through increased demographic density. The archaeological richness, as exemplified by the double cemetery of Gobero in Nigeria (Sereno et al, 2008), attests to the success of the socio-economic system (Lucarini, 2016). After a period of florescence between the 6 th and 4 th millennia, the process of aridification that had begun as a series of successive climatic crises manifested as a long-term condition, at first altering and then compromising this success, before hastening its total disappearance by the end of the 4th millennium. 
Thus, for a certain period of time, the central highlands of the Sahara supported a pastoral lifestyle, playing much the same role as did the Nile Valley in a different context. The mountain already frequented by the "Round Head" populations, whose specific worldview is expressed in their sacred places, became attractive grounds for browsing and grazing due to patterns of orogenic rainfall (Fig. 1, Fig. 2). From the combined effects of the success of pastoralism and the constraints of climate in a populated world, a psychological tension must have emerged, centered on the maintenance of a way of life based as much on relationships and exchange as on the tending of livestock (Fig. 3).

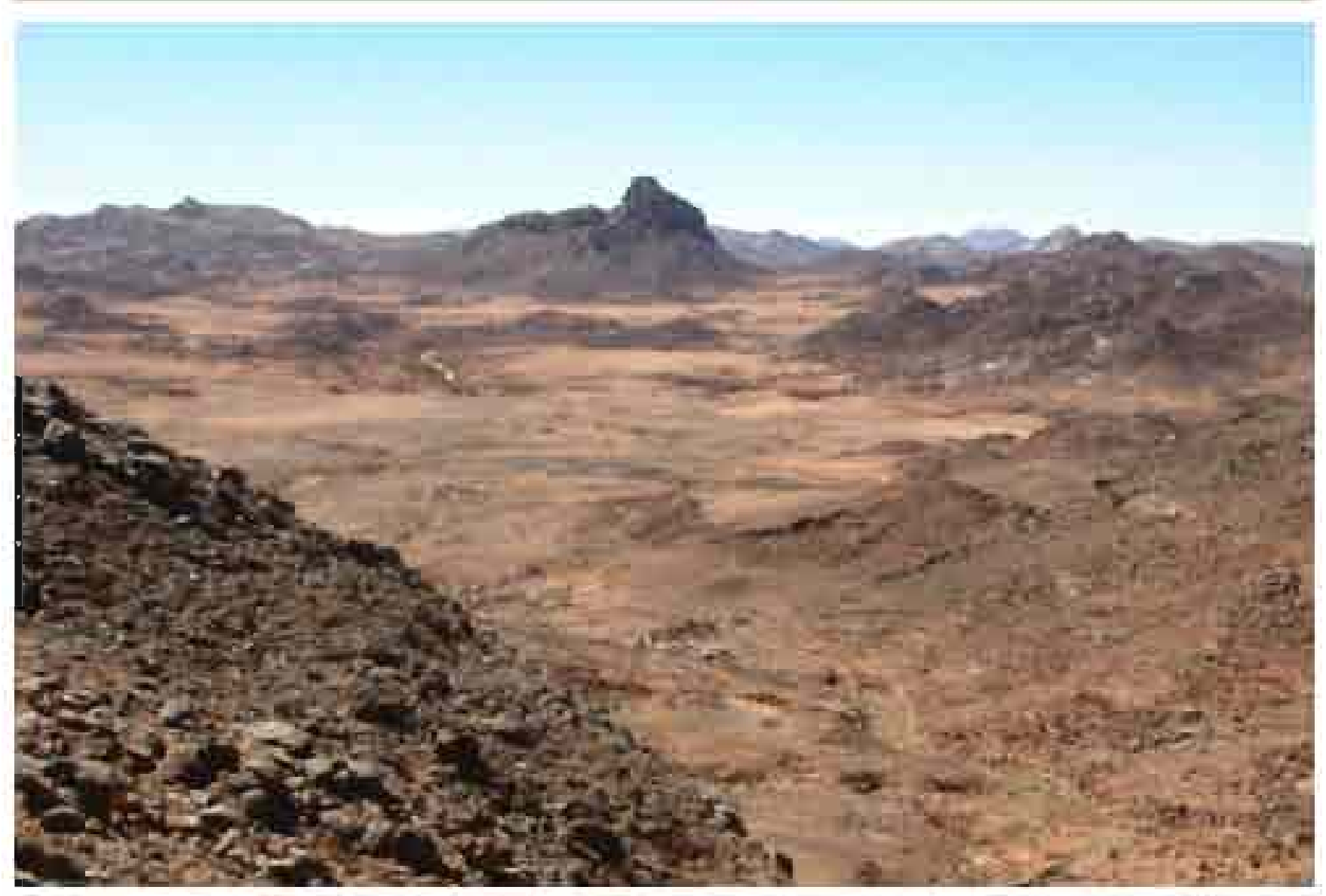

Download high-res image (1MB)

Downioad fult-size image

Fig. 1. The plateau of wadi Tahart, which has an altitude of around $1700 \mathrm{~m}$. Downstream, the wadi Tahart joins the wadi Mertoutek, and the two and other tributaries drain the slopes of Mertoutek.

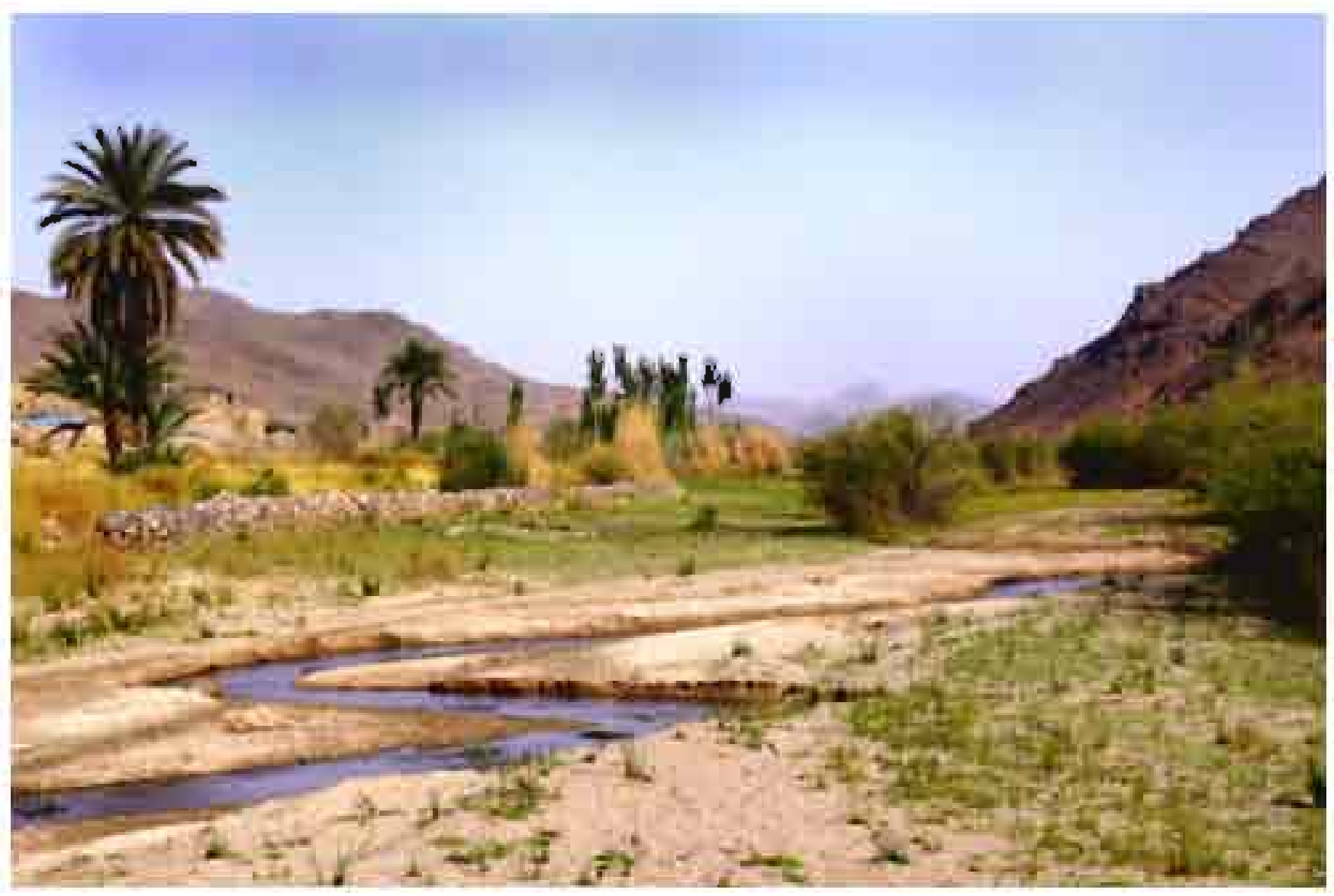

Download high-res image (1MB) Download fult-size image

Fig. 2. Wadi Mertoutek (Téfédest chain of the Hoggar Mountains, Algeria). The rains favored by altitude stlll feed the wadi today. This natural water fiow. on the surface or subterranean, facilitated the growth of a range of plants in the valley's basin (durum wheat, diverse vegetabies; fruit trees including: grapevines, pomegranates; figs, date paims...) 


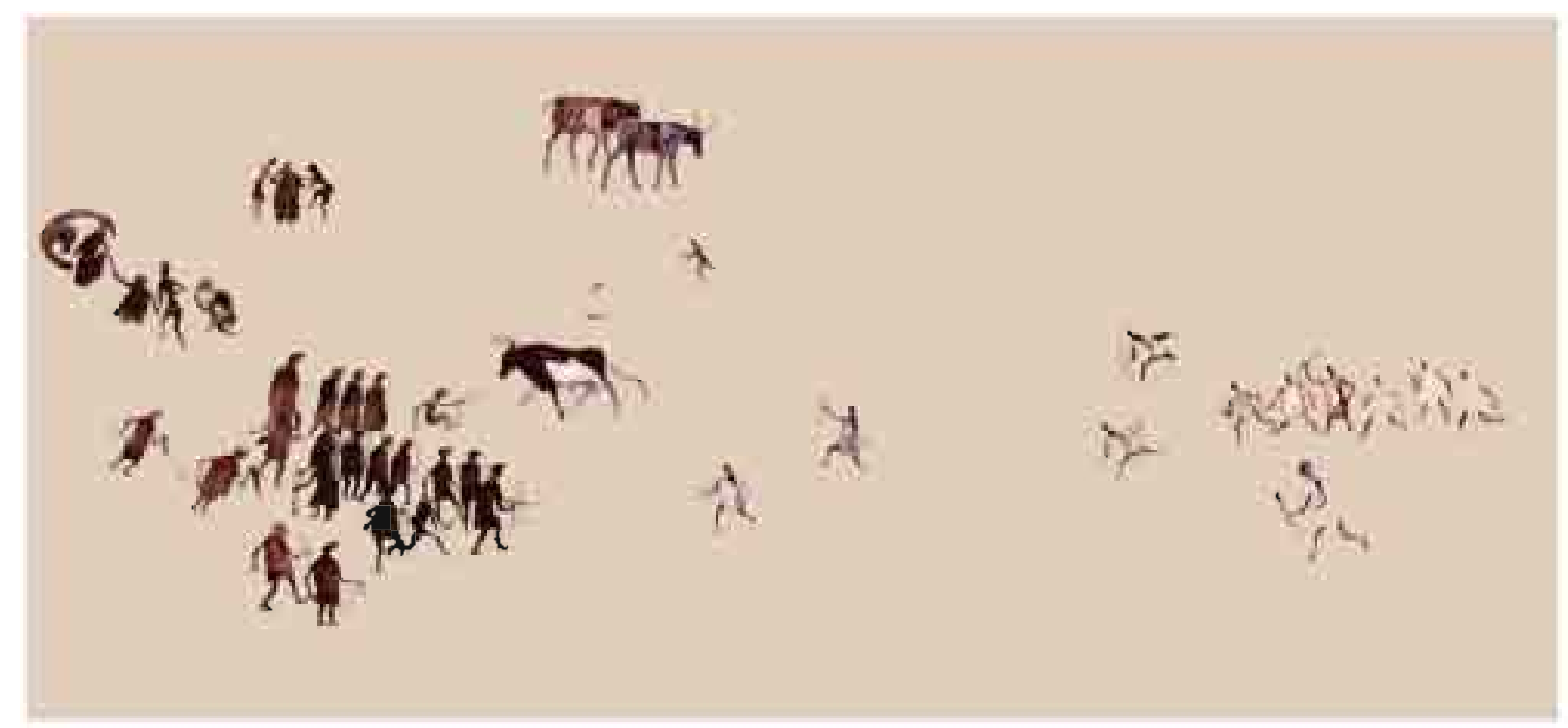

Download high-res image (225KB)

Download full-size image

Fig. 3. Wan Amil (Acacus Mountains, Libya). The grand composition of Wan Amil (detail of the central scene), An influx of people into a campsite, with people executed in red ochre and wearing a hairstyle of the "Wan Amil" type, and a bovid followed by a group dressed in ample white robes (after Morl, 1960; after dl. Lernia and Zampettl, 2008). (For interpretation of the references to colour in this figure legend, the reader is referred to the web version of this article.)

Confronted in this manner with the consequences of their success on one hand, and with environmental degradation on the other, the Saharan pastoralists established a discursive system in keeping with their values and representations of the world that was capable of regulating social relationships between individuals and groups and thus avoiding conflict between them.

\subsection{From story to myth and from myth to image}

According to Claude Lévi-Strauss, myth in its formative phase is a form of collective psychosis based on a foundational discord or problem. In the context of Saharan pastoralism, this foundation could well have been generated by these two antagonistic psychological constraints. This initial inception of myth is certainly anterior to its verbal formulation in the form of story (Lévi-Strauss, 1979) and to its graphic representation in the form of rock art (Fig. 4). Therefore, the archaeologist must resign to trace in reverse the order of conception and execution of works of rock art and to recover in this manner the line of thinking that shaped them. One can hope to arrive at the formation of the myth, to perceive its nature through its structure, that is to say: the essence that justifies it and is also the fundamental explanation for rock art. 


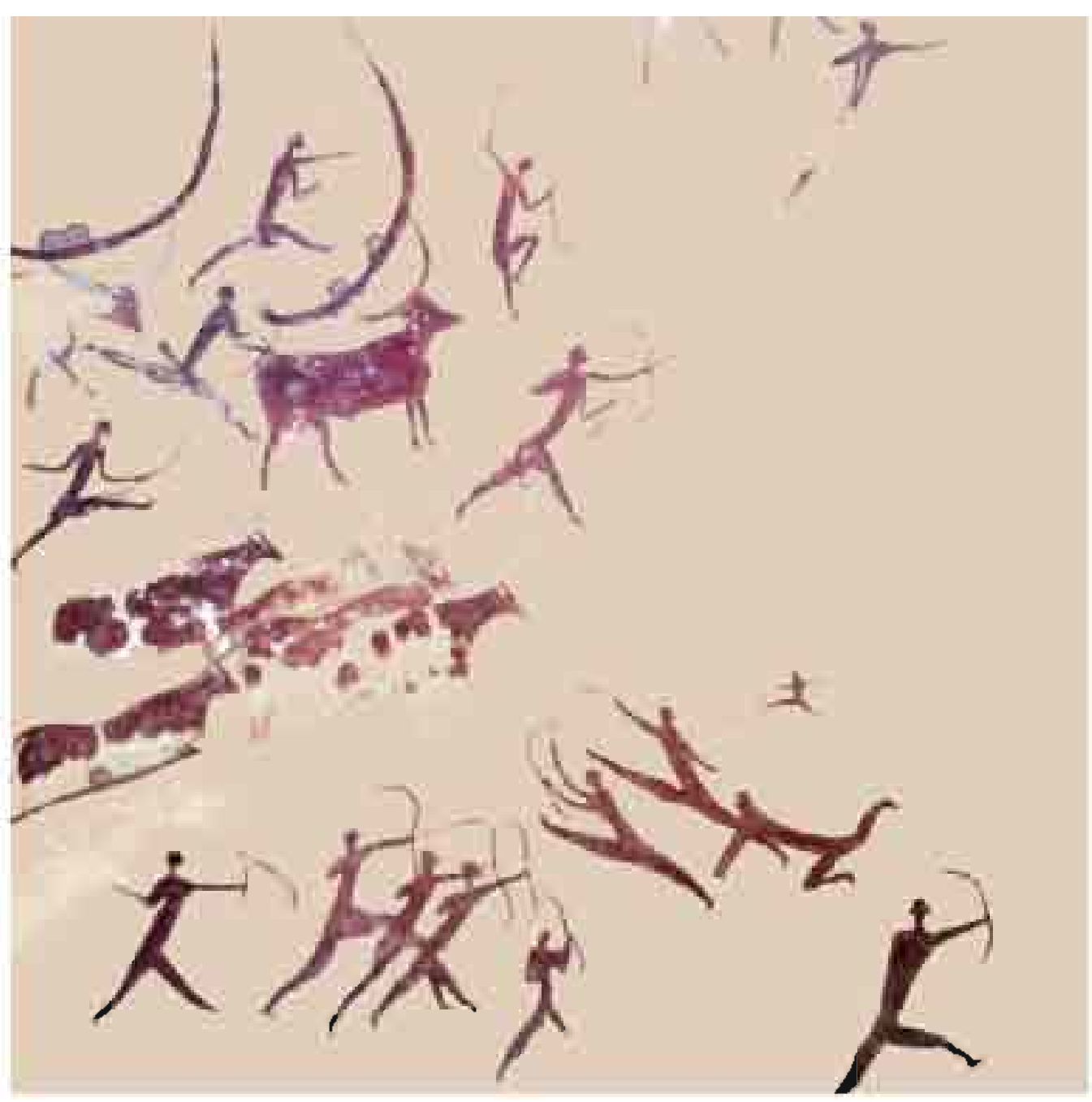

Download high-res image (411KB) Download full-size image

Fig. 4. Jabbaren (Tassili-n-Ajjer; detail). Virtual combat around a small herd on the move.

At variable levels and with diverse intensity, the relationship between a myth and it's source in reality is of a dialectical nature, such that "the institutions described in the myths can be the very opposite of the real institutions. This will in fact always be the case when the myth is trying to express a negative truth." (Lévi-Strauss, 1967: 29). Thus, instead of a faithful chronicle of a significant moment in the daily life of prehistoric herders, we could encounter here and there the idealized form of this moment (Fig, 5).

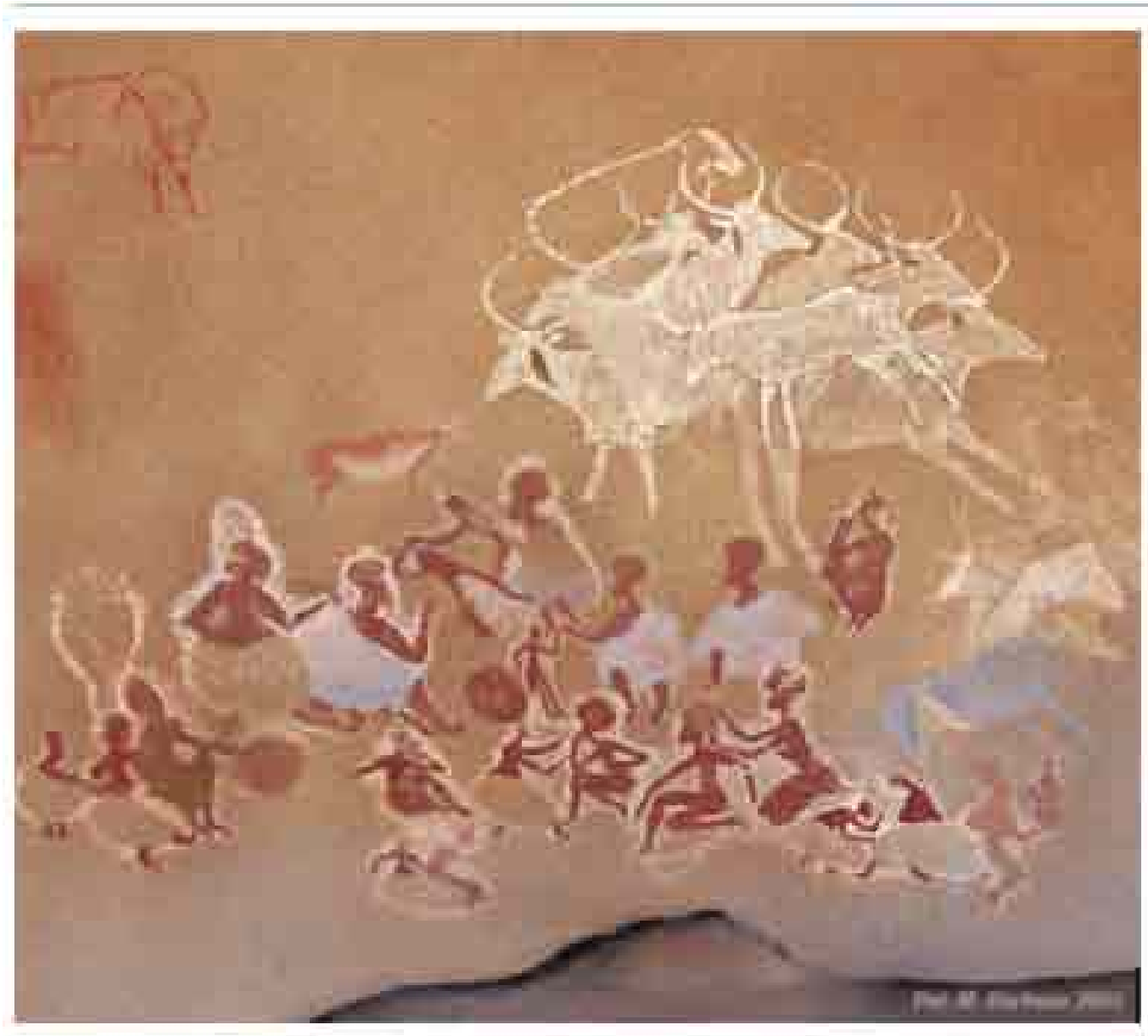


Discourse serves to reify an idealized vision of a society capable of controlling the relationships between its members. Permanent allusion to violence (Fig. 6) serves to denounce the use of force, but also serves as a reminder that violent force it is a necessary and legitimate recourse (Fig. 7). This discourse regulates the exchange of goods and services between people, as suggested by the representations at Tikadiouine (Fig. 8) and Tissoukaï (Hallier and Hallier, 2013), much like the reinforcement through ritual and sacrifice of the collective values and behaviors that sanction and sanctify the social contract. A specific development about the rites would be doubtless of the highest interest, because a knowledge of the rites would help us to understand the relation to the world of these people, mainly herders of the Saharan Final Neolithic, as we have attempted to do in a previous work (Barbaza, 2015: 205, 210, 219). It is difficult to address this domain because the graphic documentation is quite limited and does not allow us to access the different phases of the rites. In most cases, the graphic representations only hint at rites. There is little doubt that some of these images were perceived by the prehistoric viewer as representing an explicit practice, but we can hardly interpret them as classes of action, such as sacrifices, war dances, initiatory hunting, bullfighting, etc.

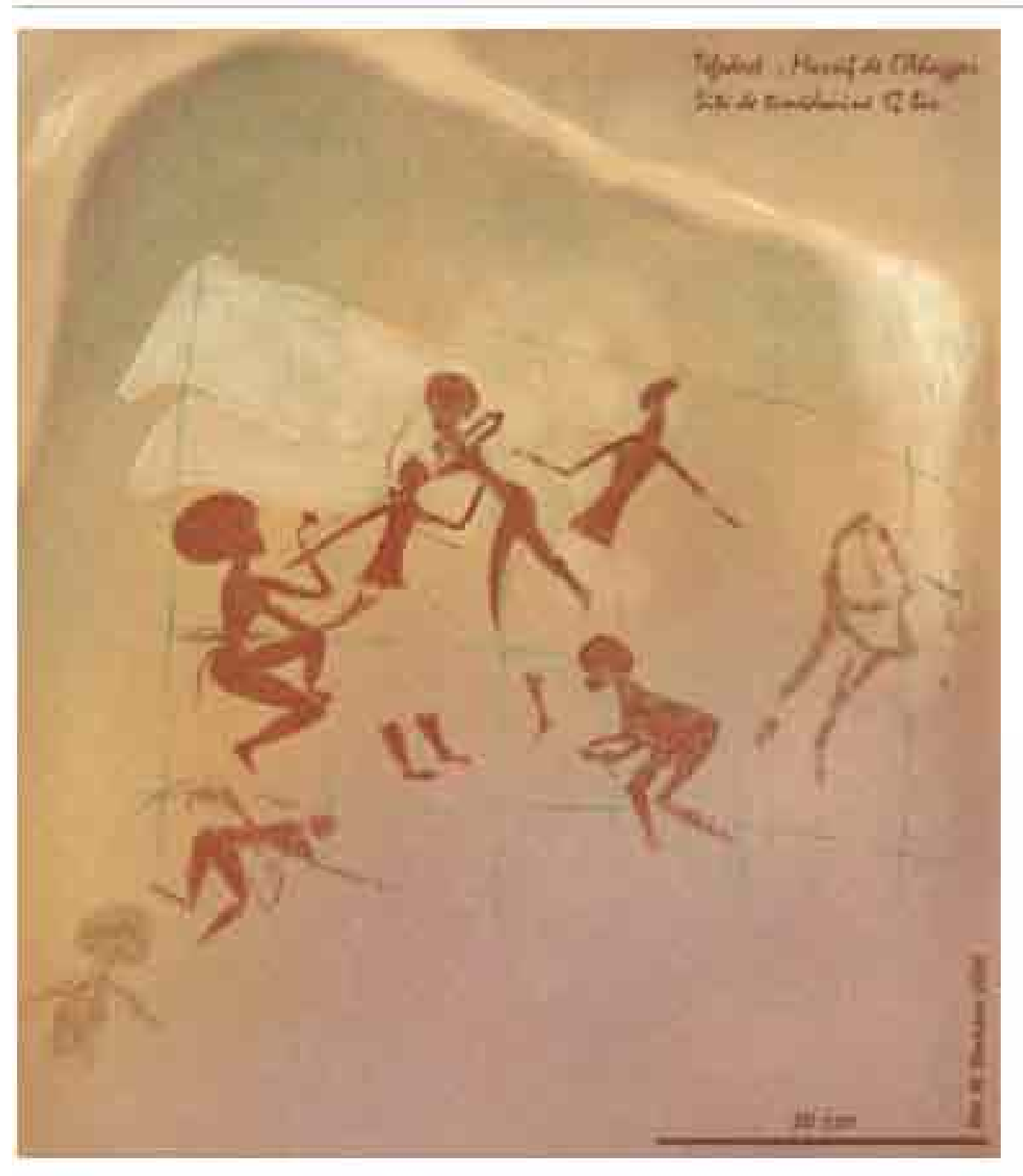




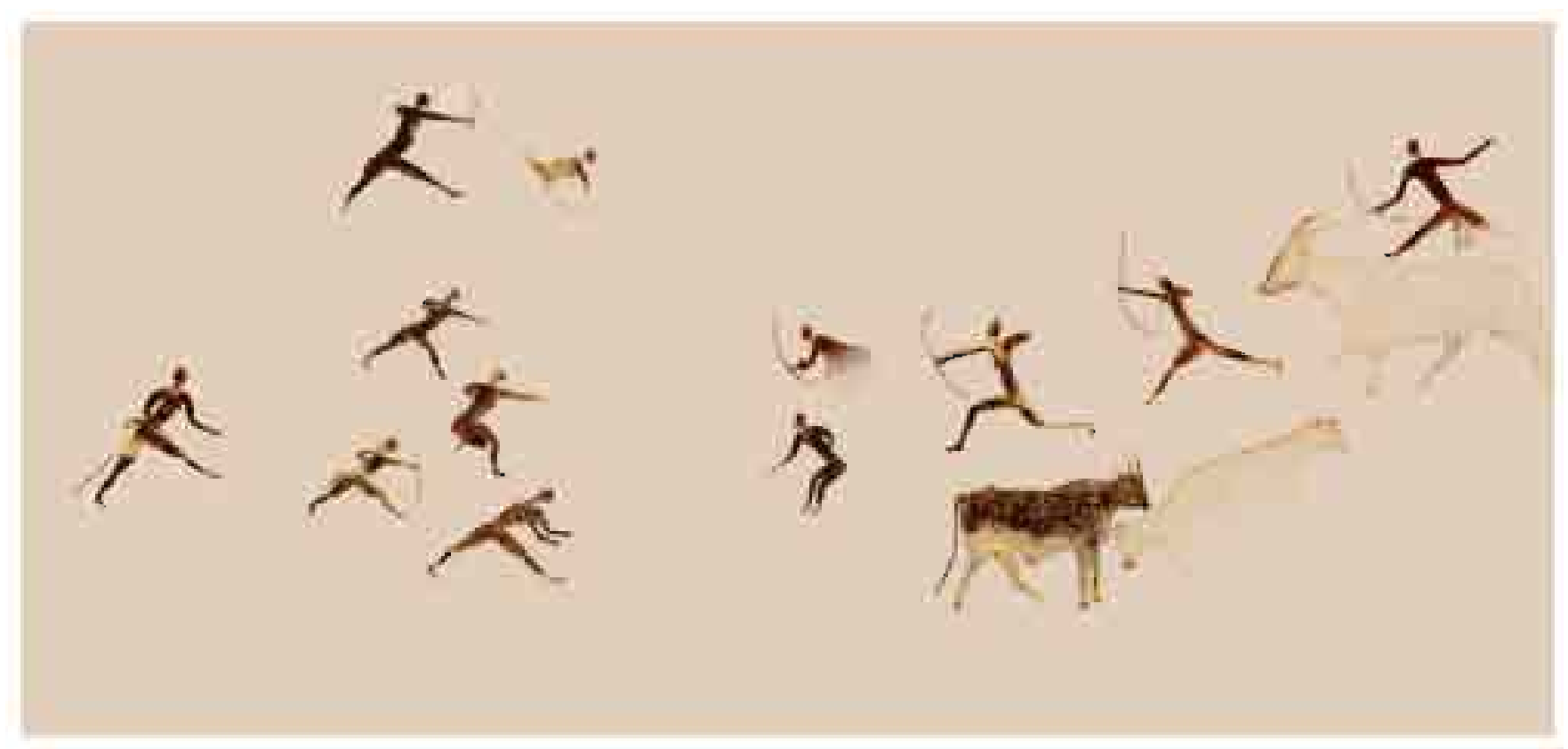

Download high-res image (274KB)

Download full-size image

Fig. 7. Sêfar (Tassili-n-Ajjer). Amed confrontation near several heads of cattle.

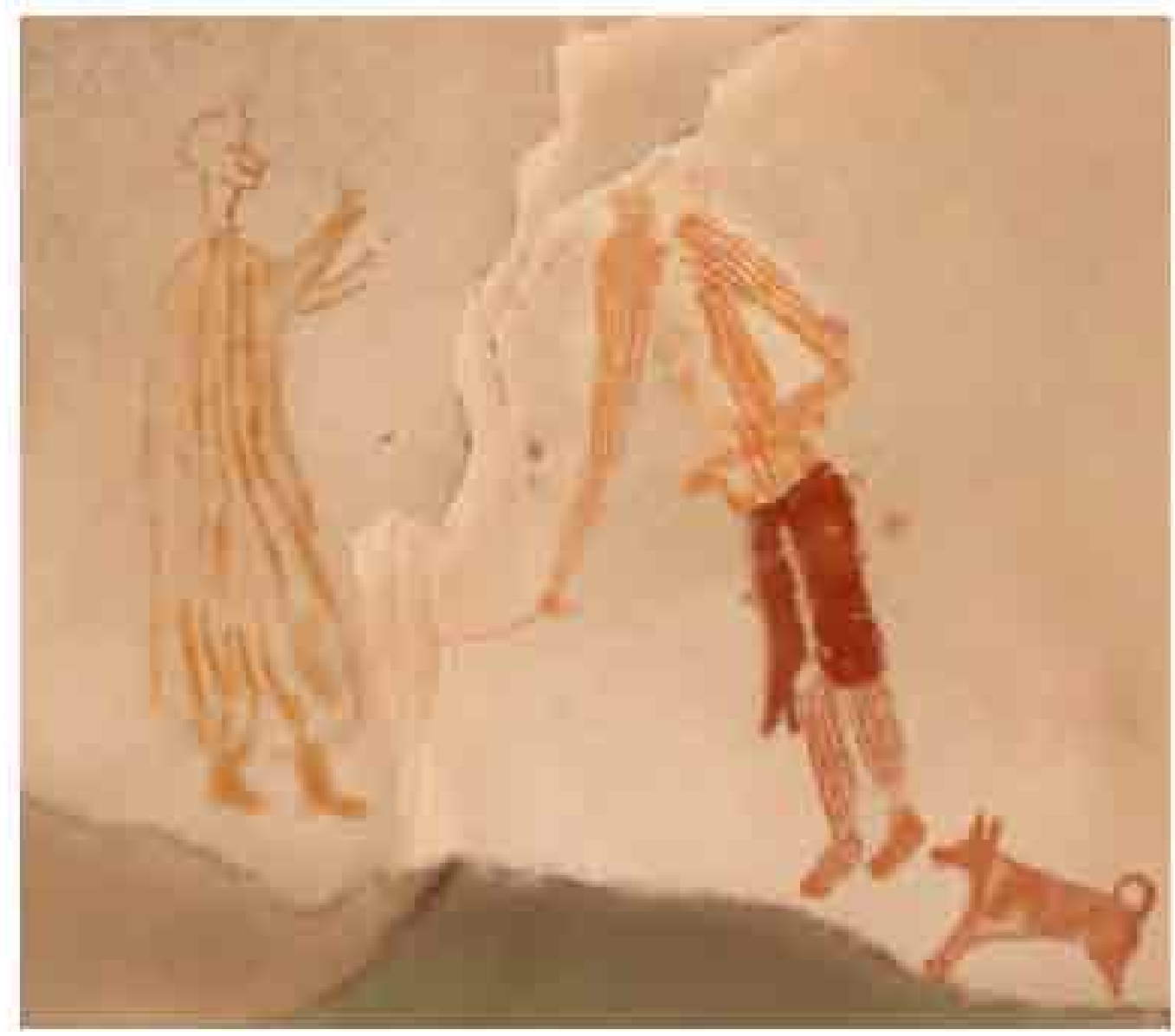

Download high-res image (502KB) Download full-size image

Fig. 8. Tikadiouine (Tassili-n-Ajjer). Detail. (Rendering by M. Barbaza).

To insist on the importance of rituals, let us remind that "it is on the basis of rites that the legends may be explained" (Dumézil, 1924) and that "the myth, negatively marked by the tensions and constraints which engender it, explains nothing, neither itself, nor something else. The myth is what should be explained. On the contrary, the rite, as a positive practice, can provide an explanation" ${ }^{\prime 2}$ (Salmon, 2013). This last sentence is rightly at the heart of the question. Our aim is to reach the origin of myth by a regressive approach, far from ethnographic comparatism, just looking at images painted of rock walls. The pictorial compositions should be considered as "crystallization" of the mythological structure transcribed by the artist. Finally, the ornamental motives are the part of the graphic discourse that is the most accessible one to pre-iconographic analysis (Panofski, 1939 [1967]). 
The thematic constants, graphic recurrences, and structural similarities revealed by iconographic studies-beyond stylistic traitsare among the objective elements indicative of the fundamental themes of the mythological stories of Bovidian societies. From a paleo-ethnological perspective, which involves a certain amount of speculation, the aim of interpretation is to understand the function of the story presented, presumed to be mythological, and in doing so to approach the function of rock art, working in reverse order.

The formal reduction demanded in making an image requires that the artist retain the essence of the mythic representation. This can be achieved by respecting (in whole or in part) the chain of events in the story or (through metonymy, synecdoche, symbolism, and/or allegory) by allusion to the story in the form of significant moments of the whole or abstract/schematic notations of them (Sauvet, 1979, Sauvet, 1988, Sauvet and Wlodarczyk, 1995).

The most talented of artists attained an apogee of aesthetic achievement in combining the dynamic qualities of striking realism with a semiotic function that would have been appreciable to their contemporaries (Fig. 9).

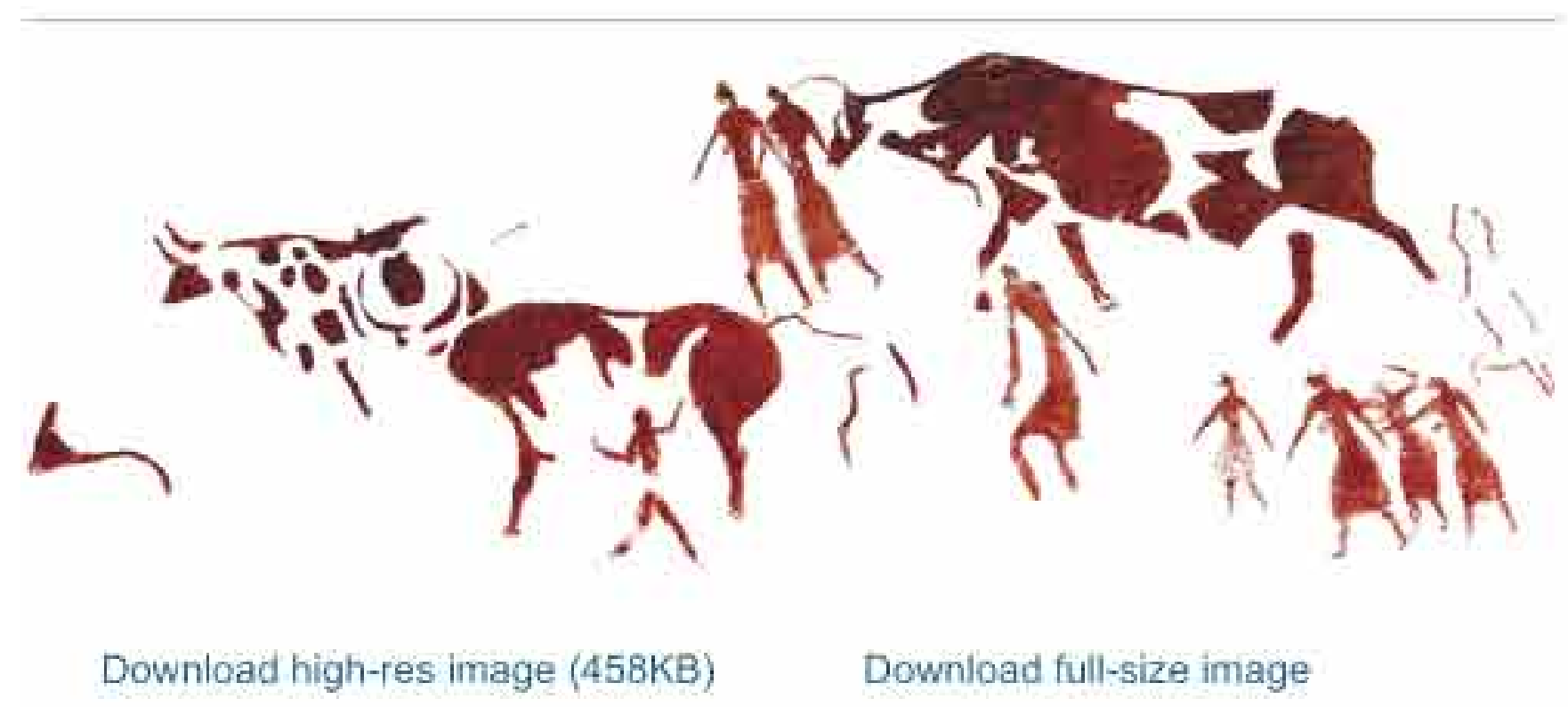

Fig 9. Jabbaren (Tassili-n-Ajier). Cattle and people on the move.

Sociocultural anthropologists teach us that mythological discourse (the myth or tale) is almost always "the story of the resolution of a conflict, or of a void, collective in the case of a myth and individual in the case of a tale, that would have been filled through human

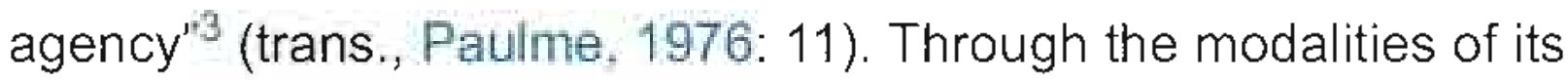
wording, through its representation in the form of mental images or, for us, graphic representations (Barbaza, 2015), and especially through the understandings of its roles and functions according to structural anthropology, what is expressed by myth is essentially an idealized form a reality that is difficult to face, imposed by the confrontation of humans with each other and with nature (Fig. 10). 


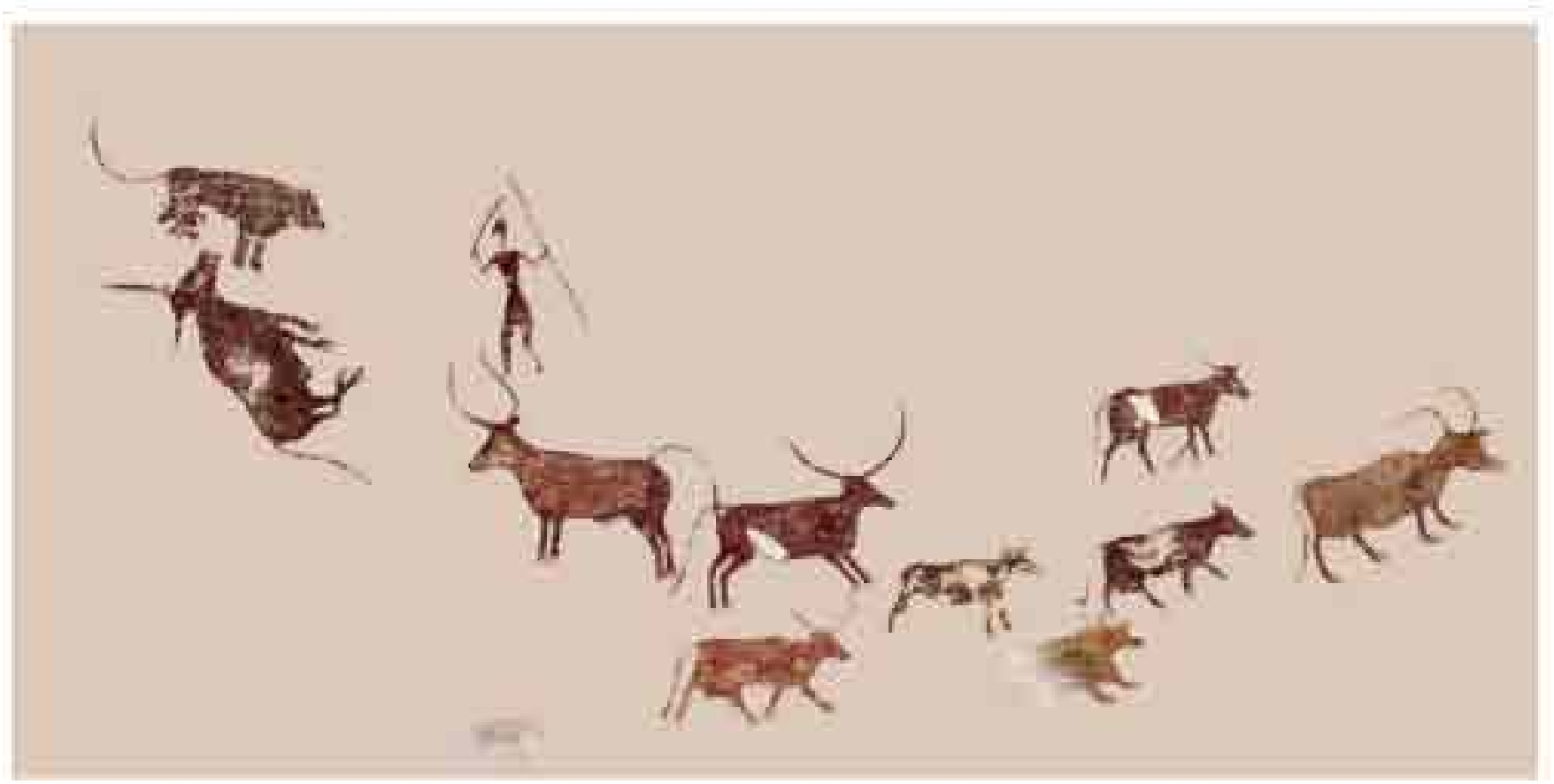

Download high-res image (286KB)

Download full-size image

Fig. 10. Wadi Aramat (Acacus Mountains). An encounter between a lion that has attacked a bovid and a concerned herder trying to protect a fleeing herd.

1.3. The function of myth. The function of rock-art images

Conflict, risk, and danger are therefore evoked in imagery in a roundabout way, indirectly and often through allusion. Scenes of turbulence, possibly a simulation of conflict (cf. Fig. 4), could have had such a function. At Iheren, such an allusion is achieved by the evocation of a lion devouring its prey, by hunters in arms, by armed ritual dance, as is also the case at In Itinen (Fig. 11). In a general sense, violence is only represented to signify the necessity of maintaining a force of response. The myth expressed by the image is conceived as a positive representation of a situation that is decidedly not. It is therefore normal that we systematically not find representations of a combative and negative reality that was understandably avoided.

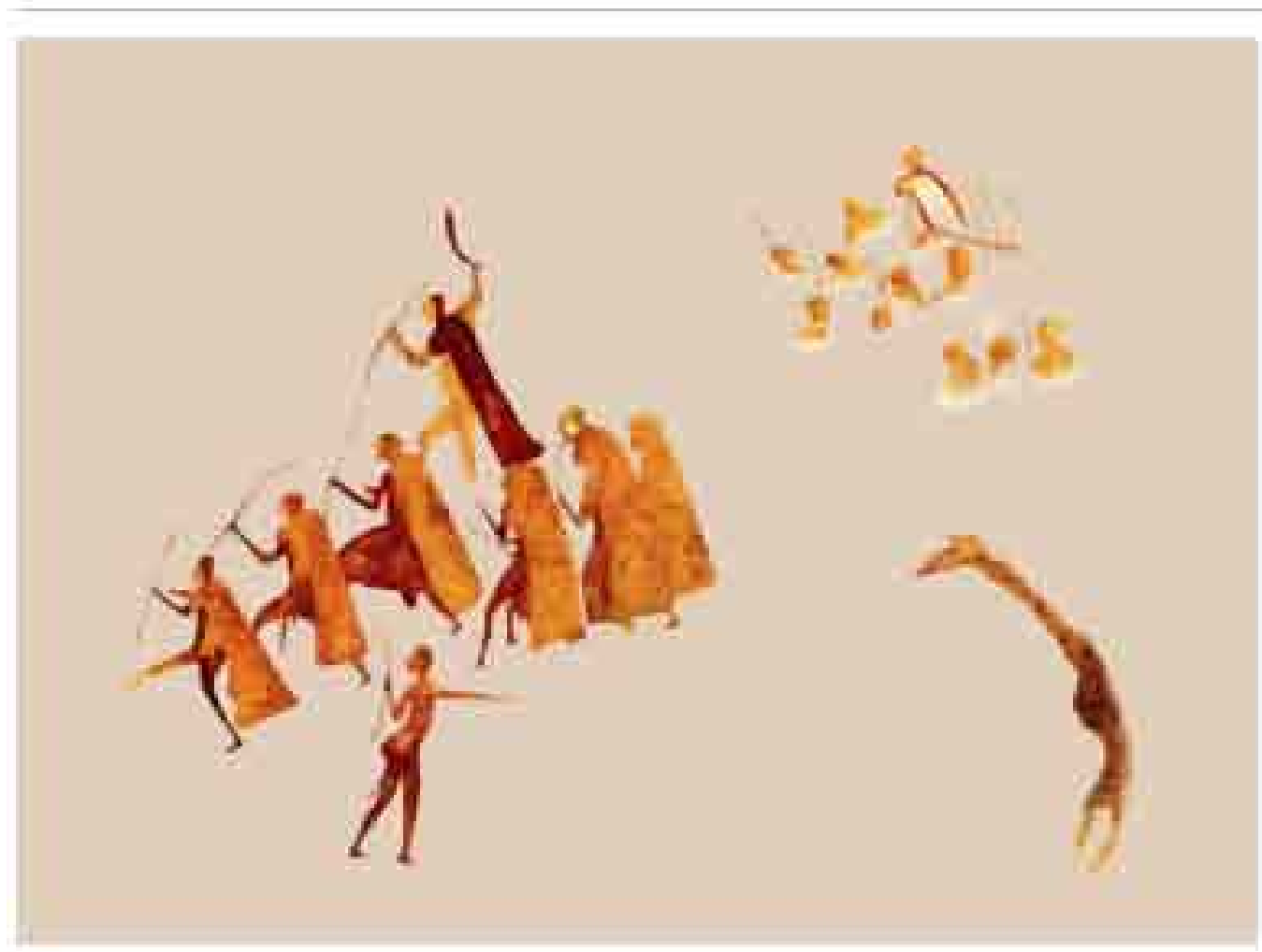


The function of myth is to express though symbolic images, for the most part literary, a web of behavioral relationships within a given social group. This collective mental structure is insidiously carried in the habitus of groups that share all or some of these behaviors. It is from and around this tacit code of behavior that mythological discourse is elaborated, as an imaginative and idealized reconstruction of a situation initially perceived as aberrant and potentially delicate. In certain cases, the myth takes form by borrowing descriptions of natural or social phenomena that serve to put it into words and, potentially, into images. The myth itself resides in its totality in the structure of the "discourse" that conveys it (LéviStrauss, 1979, Lévi-Strauss, 1996); its purpose lies in the discord between the reality it addresses and the treatment of this reality by the collective unconscious. The ultimate representation of myth presented on the decorated panel can thus be perfectly precise in its details but fairly far removed from the reality lived by the group that created it, which effectively "restrains without question the utility (of myth and its diverse evocations) as a documentary source"14 (transl., Lévi-Strauss, 1974: 209).

The function of the pictorial or graphic work of art is to render a set of concepts intelligible through the image. In packaging the former in a coherent representation, the image simultaneously presents their content and their relationships to one another. The aim of the image in rock art is certainly more difficult to capture. But is it really so different? From among a non-comprehensive list, it would be possible to evoke the search for a didactic "re-presentation" of the myth for the edification of individuals or participation in rituals that sacralize a celebrated event. In this sense, representations of collective dances (Fig. 12), if this is indeed what they are, would be a sort of mise en abime of a key moment of a ritual. It seems impossible to say so with certainty, given the absence of evidence (including archaeological sites) related to the actions that played out in their proximity.

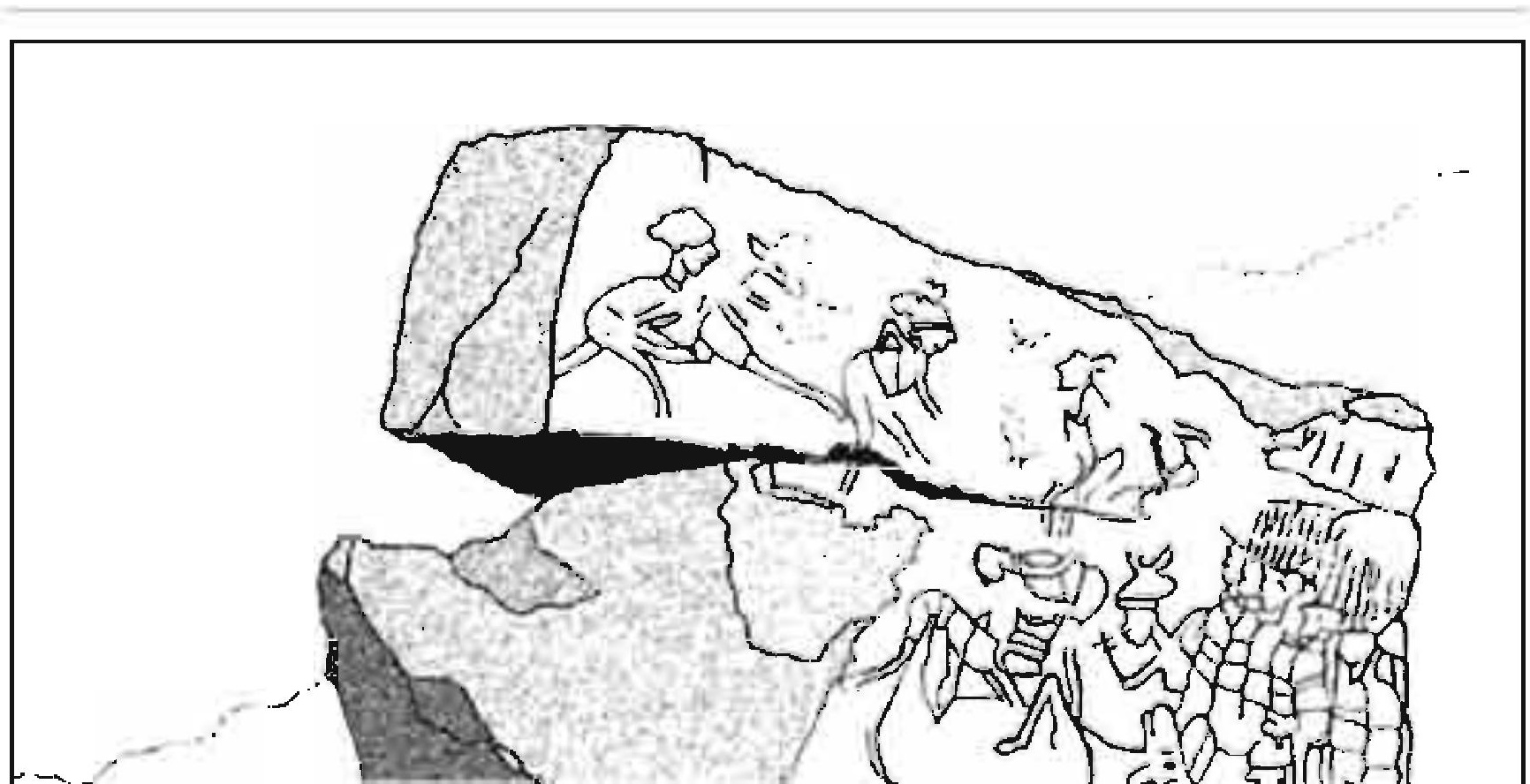




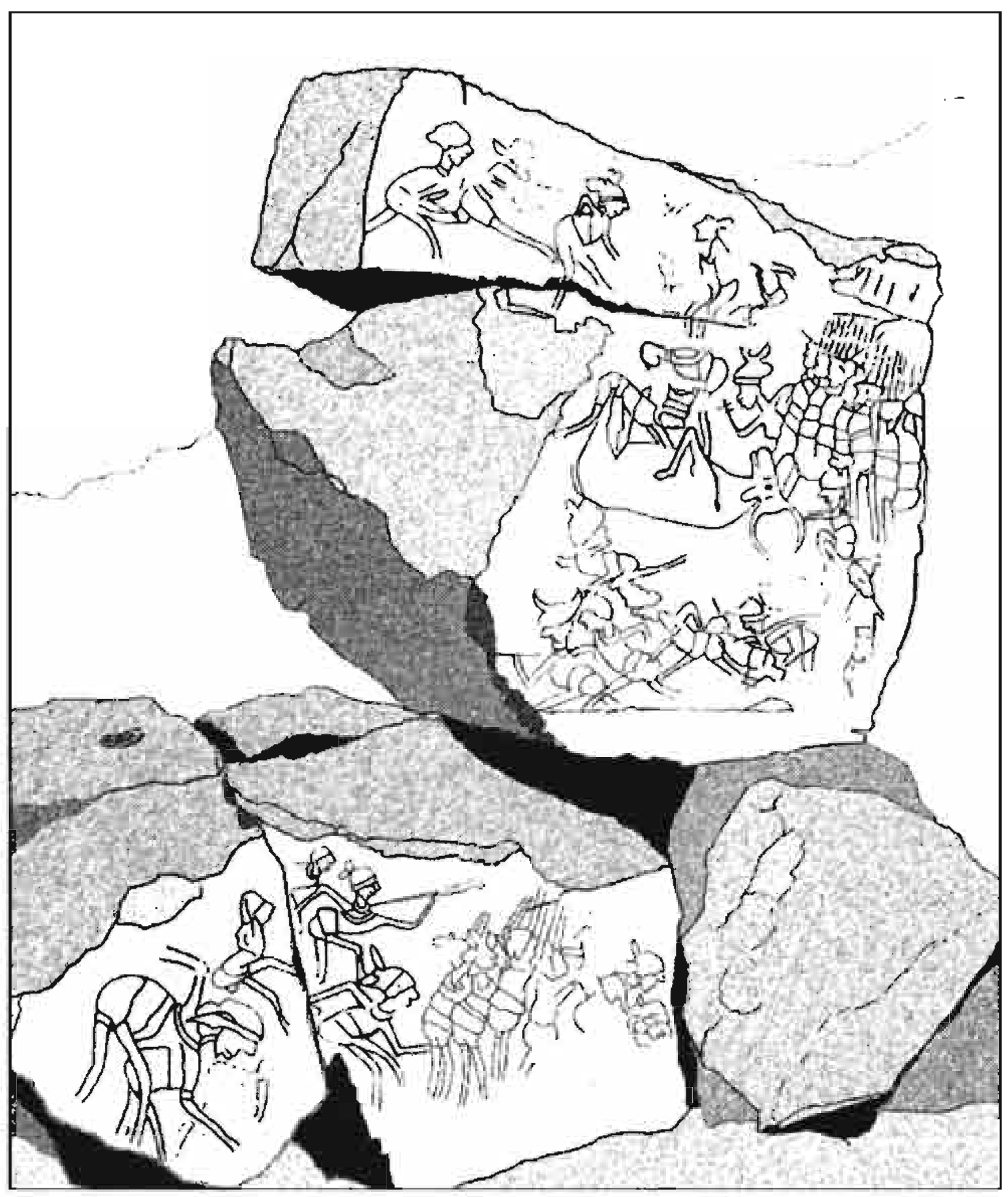

Download high-res image (2MB)

Downtoad full-size image

Fig. 12. Tin Einesnis (Messak), (detail after A.-M. and A. Van Albada, 2000),

This engraved panel shows the butchering of a bovid and a warriors dance simultaneously.

In an effort to identify a potential link between climatic decline and an increase in violence, it seemed necessary to construct a sort of rubric with which to filter and arrange prehistoric images according to criteria of sentiments or of psychological or physical behaviors that constitute a use and/or abuse of force. Even further, it was necessary to rank these expressions of force. Rather than contrast aggression and violence, manifestations of which tend to overlap at least partially, it seemed more judicious to place them on a continuum along which these two concepts can be represented satisfactorily, though somewhat inconsistently (Tisseron, 2012: 6-7). 
2.1. From aggression to violence: an attempt at definition

Violence constitutes one of those "universals" of human behavior independent of the cultural context in which it occurs, in space as much as in time. Representations of violence have been sufficiently recognized, explored, and described that one can reasonably attempt to use this mental "matrix" (Héritier, 1999) in an archaeological, and more precisely anthropological, approach to prehistoric rock art. As mentioned above, in the effort to examine the relationship between climatic degradation and increased violence, a rubric was developed for the classification of prehistoric images in terms of the intensity of the use of force, both physical and psychological. In this manner, we can recognize the following in terms of increasing degrees of vehemence: the mental state of benign aggression, an irrepressible but often restrained sentiment; the state of aggression that takes on physical expression and that includes an aspect of violence; legitimate, codified violence, such as symbolic sacrifice; malevolent aggression or transgressive violence whose limits are only bounded by the imagination (Baudrillard and Morin, 2003).

\subsection{A brief typology of violence}

This natural aggressiveness is meant to assure the survival of the species at the cost of individual survival. It is in full play when it extends to an act of physical aggression aimed at suppressing a potential threat. The causes likely to provoke this aggression, though variable, are broadly similar among all animal species. In humans cognitive capacities intervene in the face of such provocation, putting into play forces of repression determined by social codes. Beyond this, violence appears as "malignant aggression," to follow Erich Fromm, who places it in opposition to benign aggression, which is an innate and necessary aspect of life (Fromm, 2001: 202-203; translated from the original French). Only man is capable of killing or causing suffering out of passion or for pleasure, manifestations (fulfilled or not) of the desire to murder, one of the three essential compulsions recognized by Sigmund Freud. The rat is capable of killing his congeners, but he does it for other reasons based on a different set of behaviors (Lorenz, 1981). Man, by inhibiting his compulsions through the function of well-established social conventions, can partially and temporarily control this behavior. He can nonetheless give it free reign if the strength of the spontaneous reaction outweighs the obstacles to its expression; indeed, because 
several times greater in Man than in the animal" under the effect of imagination (Fromm, 2001: 233 and following; translated from the original French). It is the successive facets of this diversity that the archaeologist can hope to recover through the vestiges that the process of discovery places at his disposal (Barbaza, 2015). The representation of violence takes on different forms according to which one can posit the effects (Boucheron, 2013) or in which one can recognize an individual or collective value.

\subsubsection{Feared and subdued violence}

In this first case, violence appears in the softened form of allusion (dangerous animals such as the lion; clawed or armed therianthropes; the intrusion of the uncontrolled being; ...) (Fig. 13), and of euphemism such as the hunting scene and the warrior's dance. The warrior's dance is a segment of the myth to which it gives physical expression, an abridged version of the totality of the myth in form as well as in essence (Bastide, 1968: 1082). This is even more true when the dance is reproduced as image. Violence also appeared in this softened form in the practice of sacrifice, also violence, but in the guise of curtailing, or at least containing, potential violence through by a violence that is real but weakened (Girard, 2003; Héritier, 2005, Scubla, 2005a, Scubla, 2005b, Guilaine and Zammit, 2001, Detienne and Vernant, 1979, Bloch, 1997, Bonte, 1975, Bonte, 2004, Malamoud, 1989, McFee Brown, 1987). In certain rock-art representations, the actions surrounding the skinning of an animal, or even sometimes the attention given to this act by those performing it, could suggest an « auscultation » performed by some oracle divining signs (cf. Fig. 14).

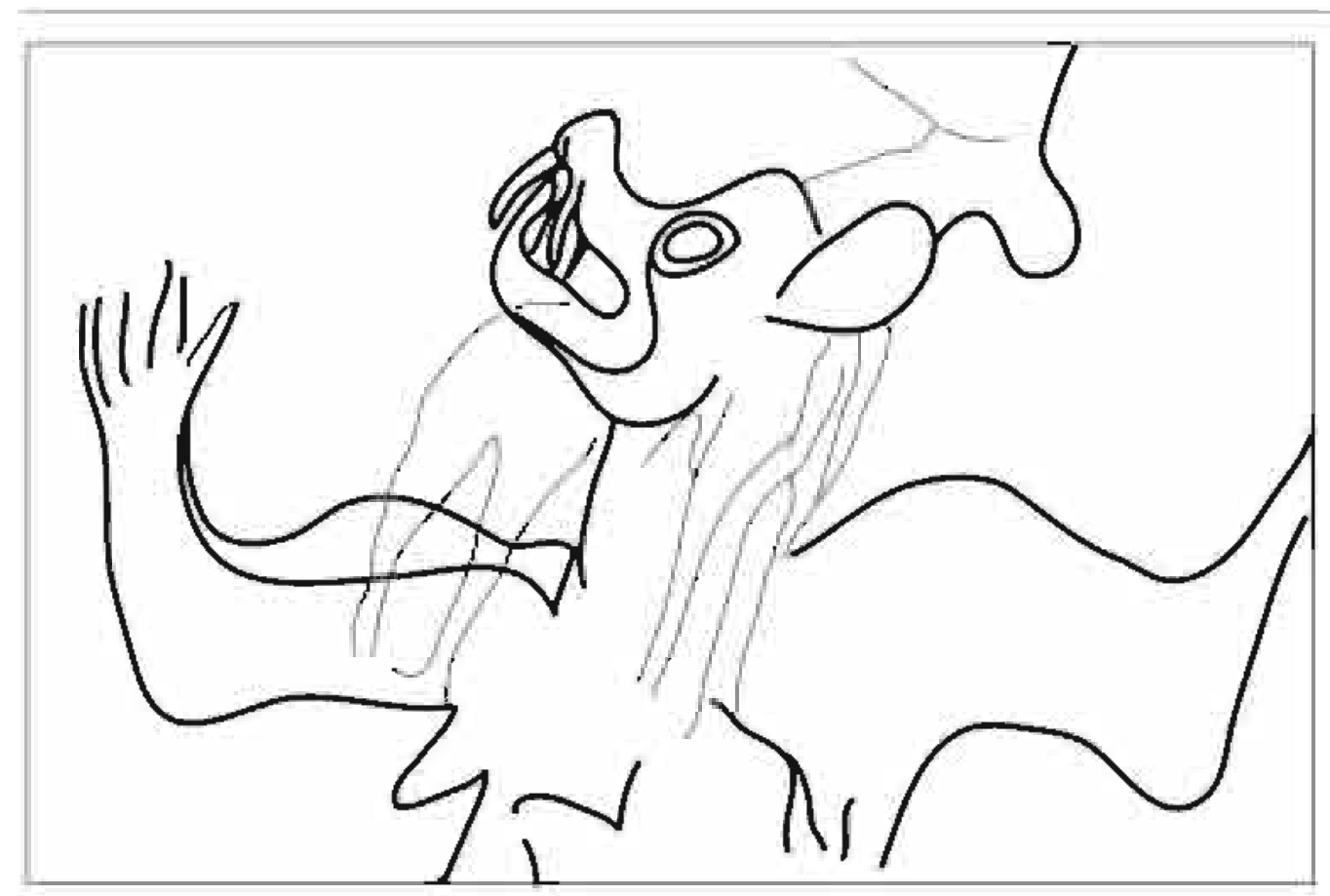




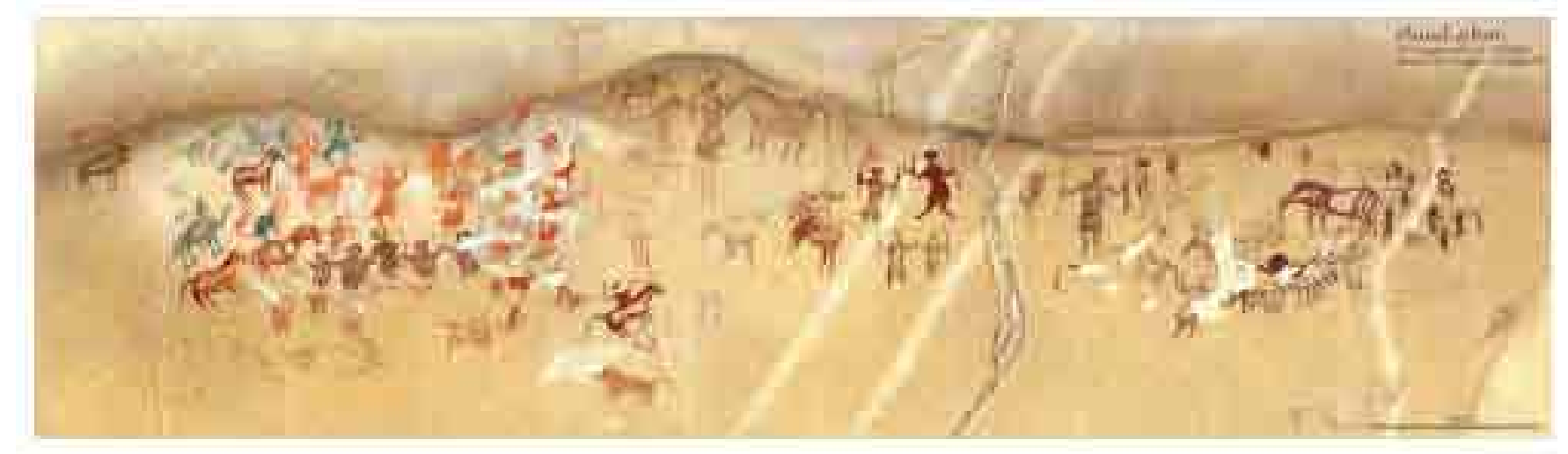

Download high-res image (3MB)

Downioad full-size image

Fig. 14. Wadi Ahor (Téfedest). Large rock shelter decorated with hunting and combat scenes (Rendering by M. Barbaza).

The great wisdom of Bovidian groups between the 6th and 2nd millennia $\mathrm{BC}$ was to put in place appropriate manners of reducing and containing violence in a living environment that had become restrictive. This so-called "culture of peace" also privileged encounters and dialogue that were preludes to the exchange of goods and people. The myth expressed by the image is conceived as a positive form of a situation that is decidedly not. It is therefore perfectly normal not to find representations of a combative and negative reality, which was precisely what was being avoided.

\subsubsection{Violence as a fundamental value}

On the contrary, during the Caballine period, violence manifests as an individual and collective value. It is magnified by the demonstrative repetition of hunting or warring actions (Fig. 14).

\section{The ideal society}

Several scenes that are unlikely to be depictions of real events suggest that many bestiary compositions play a role of symbolic representation. One can see the association, even interlocking, of wild animals and domesticated bovids. The former are usually captured in highly naturalistic poses and present an idealized vision of a parade of animals typical of the savannah from which, incidentally, the large predators have been carefully cast out: the "ideal society" in a way. Many such examples can be cited (Barbaza, 2015: 224 and following). Among the more remarkable, the large painted panel of Iheren at Tassili-n-Ajjer, exceptionally rendered by Pierre Colombel and Yves Martin during the missions organized by Henri Lhote, as well as the engraved panel of Tilizaghen at Messak, which are notable for the scale and visibility of the compositions.

On the first of these panels, several different species are gathered in a limited space. The wild animals are captured in naturalistic poses 
On the first of these panels, several different species are gathered in a limited space. The wild animals are captured in naturalistic poses borrowed from ethological observations: an antelope and fawn, gazelles, elephant, a herd of ostriches... Particularly remarkable in this case is the representation of a group of giraffes, each in a lifelike position, including the impressive combat displays performed by the males for dominance in a herd and tend not to result in death or injury. Another remarkable aspect is the presence of several domesticated animals, with bovids separating from the herd and blending in with the animal life in general. It is certainly tempting, though unverifiable, to associate these bovids with the human group. Along this line of thought, wild animals would become emblematic of foreign groups. The harmonious reunion of all but the most ferocious among them would constitute an example of peaceful coexistence and, more simply, a way of life. Iheren would therefore be a model of idealized society in which the animal world placed at the end of the composition would reify a sublime ideal.

At the site of Tilizaghen in the Messak Settafet (Allard-Huard, 1994: 72), a similar interweaving is seen with a large giraffe and elephant superimposed over bovids, but with the lines forming the outlines blending in an ambiguous graphic relation. This idiosyncracy is illustrated by the front hoof of the bovid with a collar and pendant, on which the deep engraved line is interrupted by contact with the front hoof of a giraffe to continue in the form of a fine line past this boundary. The order of execution is far from clear. The body of the elephant is similarly crosscut by lines that don't belong to its outline. It is clear that this element of the composition also refers to an overall image of strong association between wild and domesticated animals, exclusively herbivores (Fig. 15).

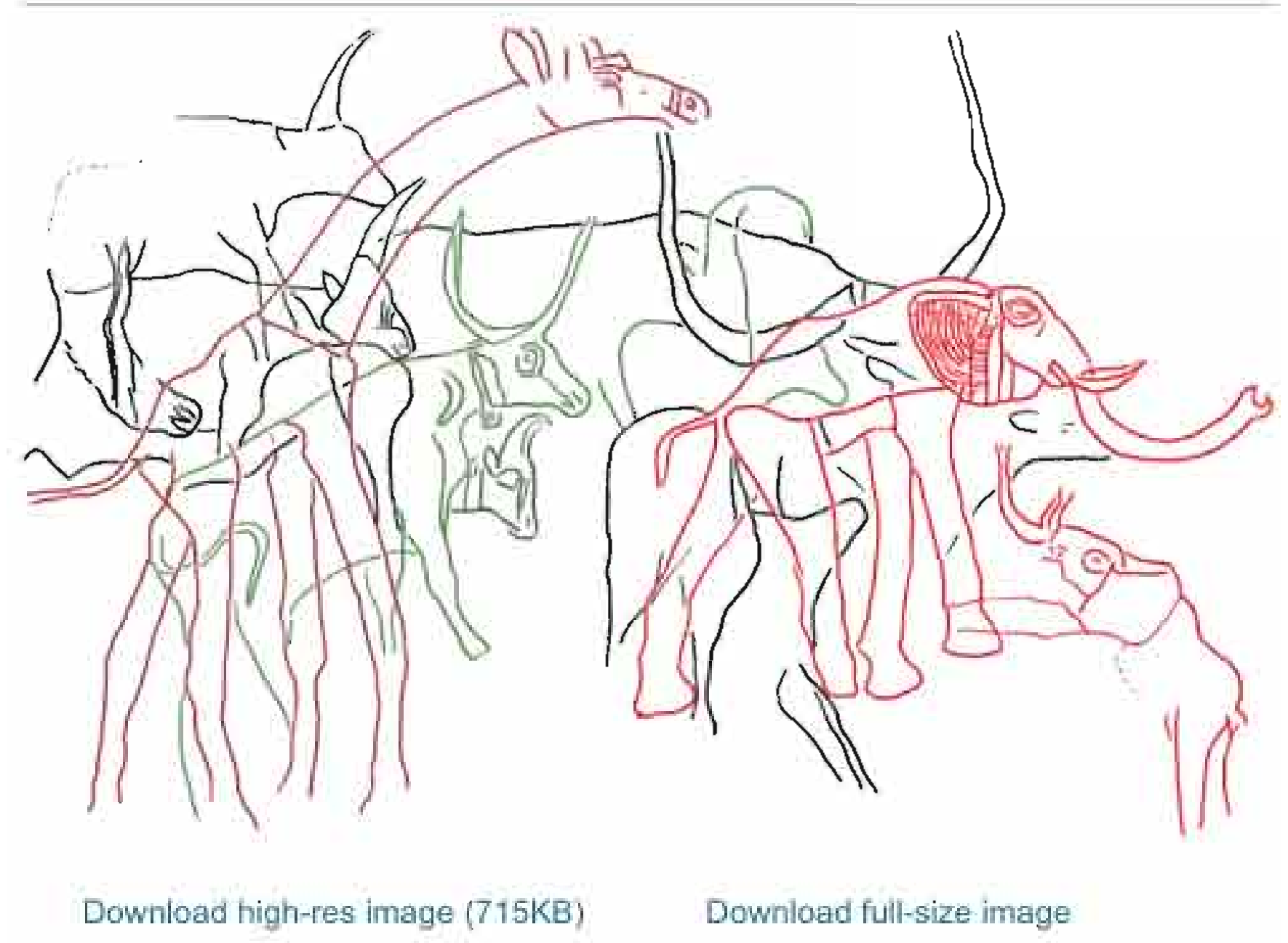




\section{Staving off violence}

\subsection{Structures and their lessons}

To ward off violence, human groups have one other course of action at their disposal (aside from sacrifice) to reduce tension and resolve conflict. This lies in constitutive course of negotiation, a prerequisite to compromises that can put an end to conflict, or, even better, avoid it entirely. The frescos of the Saharan massifs centraux that illustrate "the colloquium," the collective discussion, are in this sense a veritable foreshadowing of modern philosophies that remind us that "only where the confines of the spoken word dissolve does the domain of violence begin, and it reigns there already, even without being provoked" (Lacan, 1966; translated from the original French), and according to which "war is an exchange that has gone wrong, the successful exchange (of people or of goods) is a war avoided" (Guilaine and Zammit, 2001: 44; translated from the original French).

Timidouine 12 provides, in the traces of its composition, a key to the interpretation of other large ensembles. This site in Téfedest allows us to distinguish in effect between a central zone at the heart of which the principal celebrated act, the "essential scene" of the composition, unfolds: the placement of two groups around an infant (Hachi et al., 2011). The panel also establishes, in the lower sector, a section of apparently trivial domestic activities as well as, in the upper sector, the herd of bovids in compact formation (see Fig. 5).

These elements, in forms that differ slightly in certain aspects, are notably found at Irrekam Aharar (Hallier and Hallier, 2003), but also at other sites. At Iheren, an identical organization, in the general form of a horizontally-arranged composition, presents along a length of a dozen meters under the rock shelter, the essential scene in the course of establishment: the "encounter" among several groups (two or three, depending on whether or not one counts the central group, comprised of members of the two other groups as indicated by the two processions of different origins that converge to form it). All or nearly all remains to be done in the setting up of camp in this image. The central zone is already complete; the acts of civility [multiple greetings, "salamalecs", exchanges of words as indicated by hands raised to open mouths (Fig. 16); the offering of a beverage prepared in sturdy vessels...] unfolds according to the rules of good behavior at the center of a camp. Farther to the right huts are being constructed, the elements of which (posts certainly, but also perhaps mats and rugs) have been taken from the backs of bovids freshly relieved of their burdens. To the left, those who have not yet arrived hasten to make their way with their herds to the meeting place. 


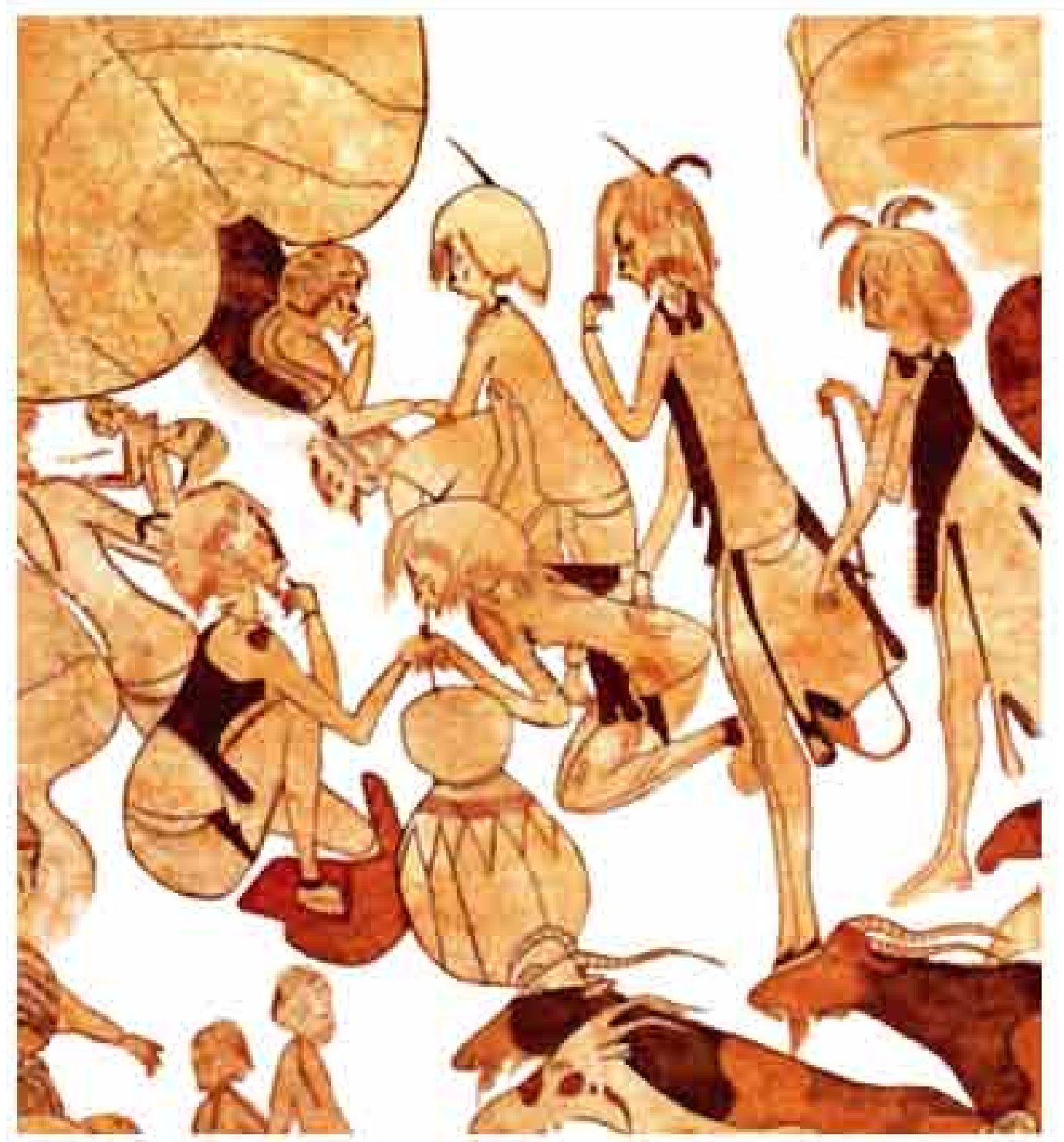

Download high-res image (868KB) Download full-size image

Fig. 16: Iheren (Tassili-n-Ajer), Detail after a rendering by $P$, Colombel and $Y$. Martin.

Along with the representation of herds in motion, the formation of camps is one of the major themes of Bovidian art. Emphasis is placed on the encounters between people, often female and seated, with the new arrivals accompanied by their herds. The shelter wall of Tikadiouine (Tassili-n-Ajjer) (Fig. 17) presents scenes analogous to those of the Iheren example.

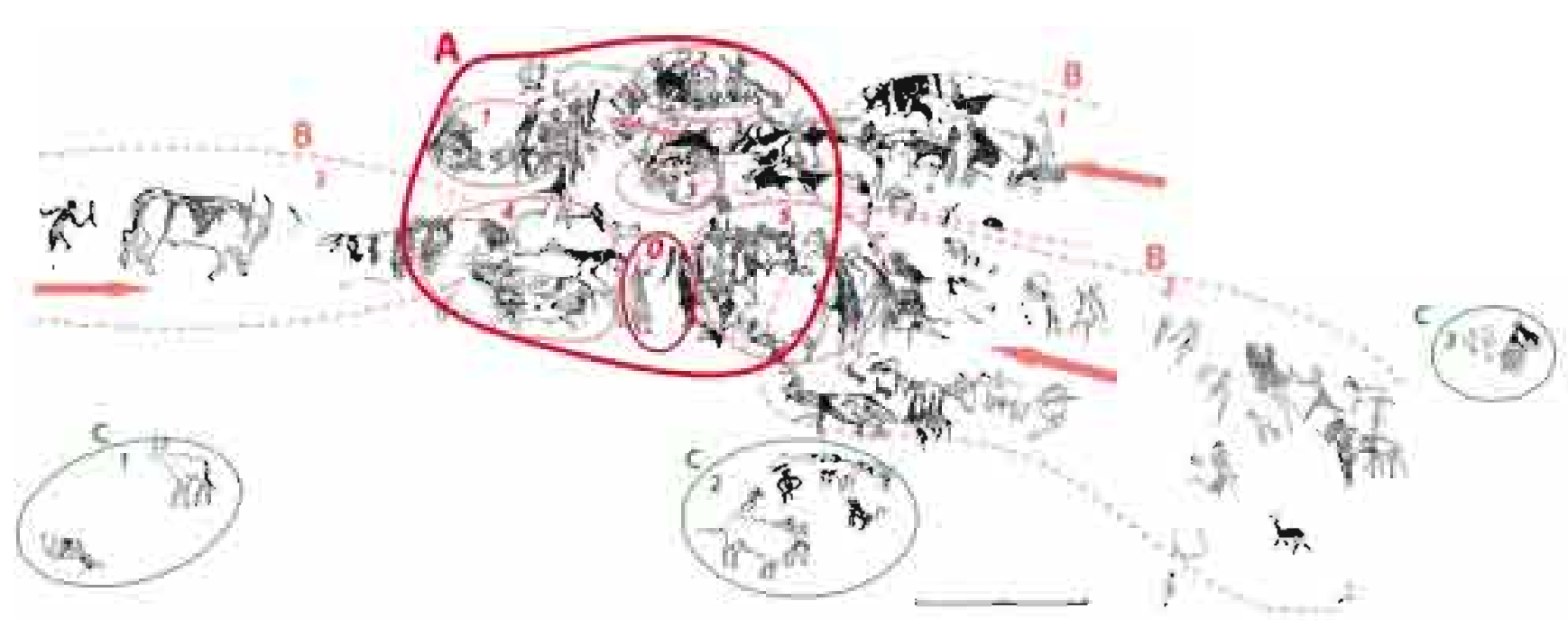

Fig. 17. Tikadiouine (Tassili-n-Ajjer). Master plan of the great fresco of

Tikadiouine shelter. It presents the same composition as Iheren (Rendering by M. Barbaza). 


\subsection{Tales and tallies}

If gatherings, dialogue, and social exchanges are good means of containing conflicts, the risks of dispute and reconsideration of illaccepted accords persist nonetheless, with their suite of quarrels and reprised hostilities. It could be to avoid the disagreements surrounding poorly conducted exchanges that the animals on the walls were painted, to ritualize exchange while glorifying certain animals, but also to establish a sort of accountability. The individualization of the animals is the strongest argument in favor of headcount of animals exchanged and not, as the "veriste" interpretation would have it, a vision of the prehistoric menagerie. Thus, one of the roles of representation becomes evident: the image could be a sort of inscribed memory, adopting in its economic character the memorial finality of writing, for which it served as a precursor (Barbaza, 2015).

\subsection{A new world}

A new ideological world appeared with Caballine art and the period of "Libyco-berber" horsemen. With the advent of protohistory violent scenes of hunting and opposing armies are innumerable, along with scenes of marketplaces, travelers, and warriors, whose general way of life, in terms of values and representations, had profoundly changed (Fig. 18, Fig. 19).
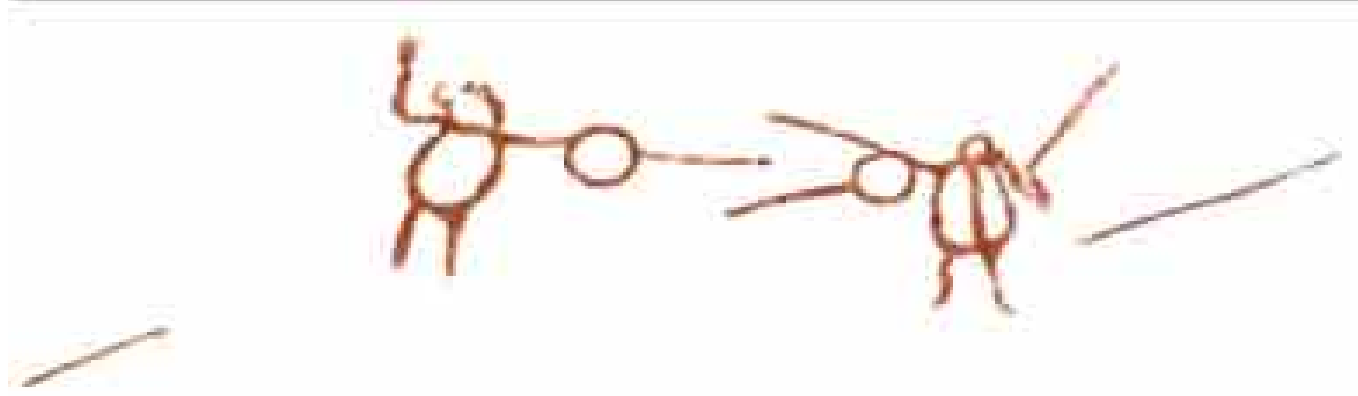

Download high-res image (64KB)

Download full-size image

Fig. 18. Wadl Ahor (Tëfedest), Duel scene (detail, rendering by M. Barbaza). 


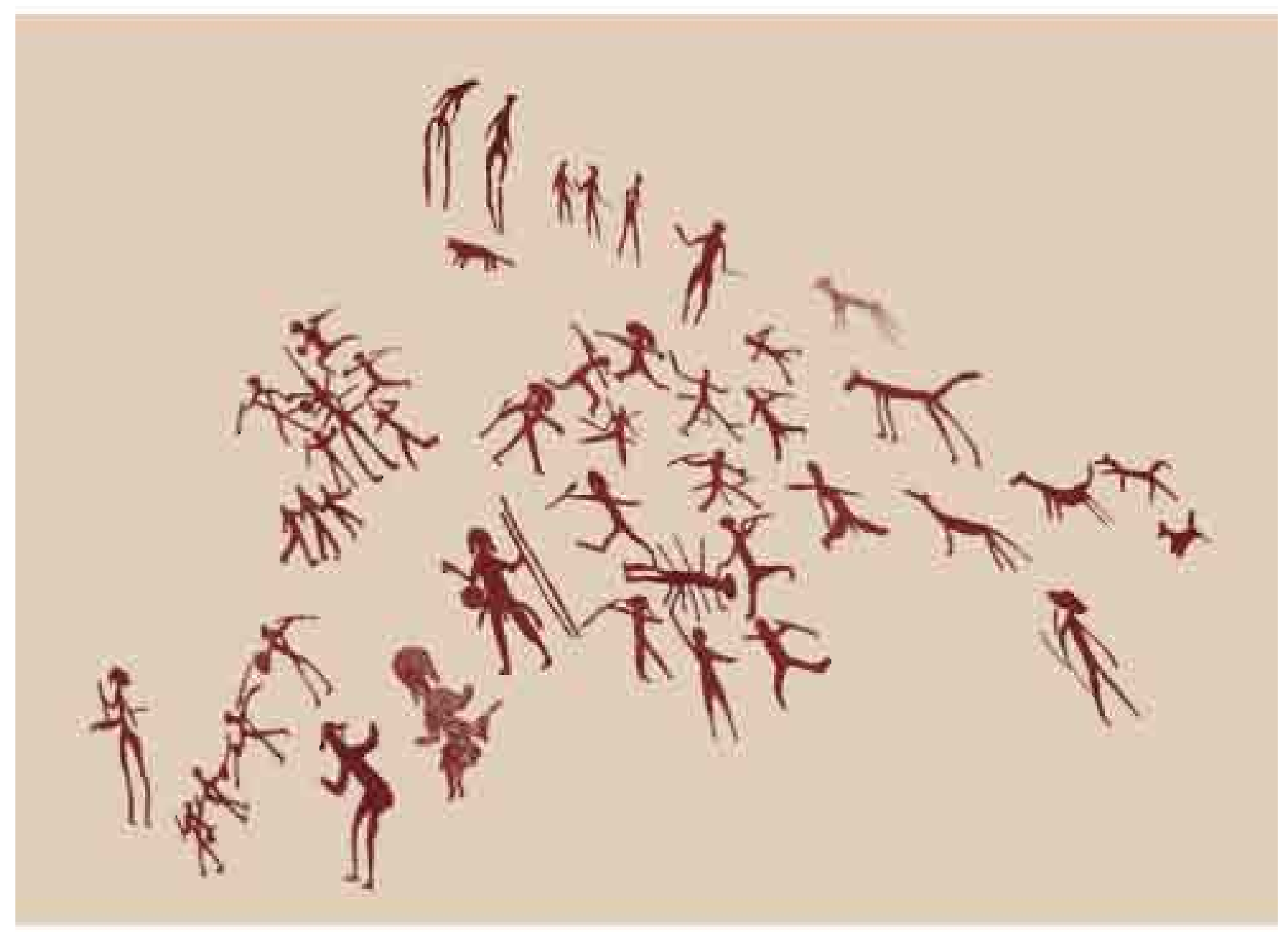

Fig. 19. In Saten (atter a rendering by Y. Gauthier).

5. The Bovidian: an art of memory

Over the course of the "Round Head" period, pastoralism, perhaps nascent already several millennia before the Bovidians, was brought to fruition by the introduction of the bovine and ovine domesticates from the Near East. The introduction of these animals was apparently accompanied by a new ideological environment, which permeated more or less rapidly and profoundly the ancient systems of representation.

Animal husbandry changed the scale of economic and spiritual life and the ecological conditions imposed ever greater constraints up to the end of the terminal Bovidian and the advent of the early Caballine. Preceding a profound turnover of mentalities near the beginning of the 2nd millennium BCE, this period of transition brought bovidian pastoralism and all it entailed to an end. 
Bovidian rock art integrated two dimensions by mobilizing the function of memory. The first is that of the accompanying myths and their preventive function. The second is that of individual preoccupations tied in part to the material interests threatened by the fluidity of memory (Barbaza, 2013). What could be more normal once societies with oral traditions started seeking to inscribe these exchanges in the sacred framework of the legends that "confer to the past a transcendent authority" (Hervieu-Léger, 1993: 125-126)? The tradition would have thus constituted a coherent ensemble of "collective significations" in which the difficulties of daily life came to be dissolved, instead of leading individuals and the group toward chaos, by drawing them into "an immutable necessary and preexisting order of individuals and groups themselves." (Hervieu-Léger, 1993: 125-126).

It is to the artist, distinguished by knowledge, by know-how, and by talent, that the task of uniting tradition and transaction fell. The resulting works combined traditional custom and daily practice in a widely intelligible whole, safeguarded from being forgotten and from the deformations likely to breed conflict of the psychological categories that are "le temps et le mo" (Candau, 2005: 28), by quite literally setting them in stone.

\section{References}

Allard-Huard, 1994 L. Allard-Huard

Les secteurs rupestres du sous-continent saharien et du Nil Les Dossiers l'Archéologie; 197 (1994), pp. 70-83: View Record in Scopus

\section{Barbaza, 2013 M. Barbaza}

La narration dans les arts rupestres du Nord de l'Afrique Les Dossiers larchéologie; 358 (2013), pp. 58-63 View Record in Scopus

\section{Barbaza, 2015 M. Barbaza}

Les Trois Bergers. Du conte perdu au mythe retrouvé. Pour une anthropologie de l'art rupestre saharien 
Barbaza, 2015 M. Barbaza

Les Trois Bergers. Du conte perdu au mythe retrouvé. Pour une anthropologie de l'art rupestre saharien

Presses Universitaires du Midl. Université Toulouse-Jean Jaures, 5, allée Antonio-Machado. 31058. Toulouse Cedex 09 (2015)

270 pp., 206 fig

Bastide, 1968 R. Bastide

\section{La mythologie}

Jean Poirier (Ed.), Ethnologie générale. Encyclopédie de la Pléiade, NRF. Gallimard (1968), pp: 1037-1090

View Record in Scopus

Baudrillard and Morin, 2003 J. Baudrillard, E. Morin

La violence du monde

Edition du Fëlin (2003)

92 pp.

Bloch, 1997 M. Bloch

La Violence du religieux

Odile Jacob, Paris (1997)

$224 \mathrm{pp}$.

Bonte, 1975 P. Bonte

Pasteurs et nomades. L'exemple de la Mauritanie

Jean Copans (Ed.), Sécheresses et famines au Sahel, II (1975), pp, 62-86

(p. 64)

Bonte, 2004 P. Bonte

Des « peuples du bétail ». Origines mythiques et pratiques rituelles de l'Elevage en Afrique de l'Est. Techniques et Cultures (en ligne)

43 - 44. Mythes. L'origine des manieres de faire. $16 \mathrm{pp}$.

(2004)

http://tc.revues.org/1116

Boucheron, 2013 P. Boucheron

Conjurer la peur. Sienne 1938. Essai sur la force politique des images Editions du Seull (2013)

388 pp.

Candau, 2005 J. Candau

Anthropologie de la mémoire

Coll. « Cursus ». Sociologie

Armand Colin, Paris (2005)

Detienne and Vernant, 1979 M. Detienne, J_-P. Vernant (Eds.), La cuisine du sactifice en pays grec, Gallimard, Paris (1979)

$336 \mathrm{pp}$. 
Dumezili 1924 G. Dumézil

\section{Le Festin D'immortalité}

Librairie Orientaliste, Paul Geuthrier éd (1924)

$318 \mathrm{pp}$.

Fromm, 2001 E. Fromm

La passion de détruire. Anatomie de la destructivité humaine

Robert Laffont éd (2001)

$525 \mathrm{pp}$.

Guilaine and Zammit, 2001 J. Guilaine, J. Zammit

Le sentier de la guerre. Visages de la violence préhistorique

Seuil (2001)

$372 \mathrm{pp}$.

Hachi et al., 2011 S. Hachi, M. Barbaza, Y. Moussaoui, S. Iddir, L. Benslama, R.

Belambri

Art et manières en Téfédest. Eléments pour un programme d'étude généralisée des vestiges culturels préhistoriques sahariens (artefacts, art, occupations de l'espace)

S. Hachi (Ed.), Préhistoire Maghrébine. Actes du Colloque de Tamanrasset, 5-7 novembre 2007, Travaux du CNRPAH, Alger (2011), pp. 145-180 View Record in Scopus

Hallier and Hallier, 2003 U. Hallier, B. Hallier

The rock shelters of Tissebouk and Irrekan Aharhar (Central Tassili, Algeria)

Sahara, 14 (2003), pp. 151-154.

View Record in Scopus

Hallier and Hallier, 2013 U. Hallier, B. Hallier

Late Bovidian rock art at Tisukä(Tasili-n-Ajjer, South Algeria) and new results Concerning the evolution of Cattle-keeping in the Central Sahara Les Can, I'AARS, 16 (2013), pp. 113-128

(fig. 26)

View Record in Scopus

Hèritier, 2005 F. Héritier

De la violence II

Odile Jacob, Paris (2005)

$350 \mathrm{pp}$.

Hervieu-Léger, 1993 D. Hervieu-Léger

La Religion Pour Mémoire

Le Cert, Paris (1993)

$274 \mathrm{pp}$. 
Lacan, 1966 J. Lacan

Introduction au commentaire de Jean Hyppolite sur la « Verneinung » de

Freud

Sèminaire de technique freudienne du 10 février 1954 (1966)

Ecrits. Ed: Seuli

http:/lespace.freud.pagespro-orange.fr/topos/psycha/psysem/hyppoli2.htm

Lem et al. 2016 R. Lem, F. Marret, J. Marshall

Towards an understanding of the millenial variability of the West African Monsoon system: combined palynological and geochemical approch

Quat. Int., 404 (B) (2016), D. 178

Article Download.PDF View Record in Scopus

Lernia, 1999 S.di Lernia

Discussing pastoralism. The case of the Acacus and surroundings

(Libyan Sahara)

Sahara, 11 (1999), pp. 7-20

Lernia, 2006 S.di Lernia

Building monuments, creating Identity: cattle cult as a social Response to rapid environmental Changes in the holocene Sahara

Quat. Int., 151 (2006), pp. 50-62

Levi-Strauss, 1967 C. Lévi-Strauss

The story of Asdiwal

E. Leach (Ed.), The Structural Study of Myth and Totemism, Tavistock,

London (1967)

$216 \mathrm{pp}$.

Lévi-Strauss, 1974 C. Lévi-Strauss

Anthropologie Structurale

Plon. 478 pp.

(1974)

Lévi-Strauss, 1979 C. Lévi-Strauss

La voie des masques

Flon, $215 \mathrm{pp}$.

(1979)

Lévi-Strauss, 1996 C. Lévi-Strauss

Anthropologie structurale deux

Pocket, Collection Agora, Plon, Paris (1996), p. 208

$446 \mathrm{pp}$.

View Record in Scopus 
Lorenz, 1981 K. Lorenz

L'Homme dans le fleuve du vivant

Collection Champs. Flammarion, 450 pp.

(1981)

Lucarini, 2016 G. Lucarini

The Neolithic from the Sahara to the southern Mediterranean coast: a review of the most recent research

Quat. Int., 410 (A) (2016), pp. 2-5

Article $\approx$ Download PDF View Record in Scopus

Malamoud, 1989. C. Malamoud

Cuire le monde. Rite et pensée dans l'Inde ancienne

La Découverte, Paris (1989)

$336 \mathrm{pp}$.

McFee Brown, 1987 R. McFee Brown

Religion and Violence

Westminster Press, Philadelphia (1987)

$106 \mathrm{pp}$.

Paulme, 1976 D. Paulme

La mère dévorante. Essai sur la morphologie de contes africains Collection « Tel. Gallimard. 323 pp.

(1976)

Petit-Maire, 2012 N. Petit-Maire

Sahara. Les Grands Changements Climatiques Naturels

Errance. 191 pp.

(2012)

Panofski, 1939 E. Panofski

Studies in Iconology

(1967. Essais diconologie: Edition française. NRF. Editions Gallimard, 394

pp.)

(1939)

Salmon, 2013 G. Salmon

Les structures de l'esprit

Collection Pratiques theoriques

PUF (2013)

$289 \mathrm{pp}$ 
Sauvet, 1988 G. Sauvet

La communication graphique paléolithique (de l'analyse quantitative d'un corpus à son interprétation sémiologique)

L'Anthropol. t, 92 (1) (1988), pp. 3-15

View Record in Scopus

Sauvet, 1979 G. et S. Sauvet

Fonction sémiologique de l'art pariétal animalier franco-cantabrique

Bull. Soc. Préhistorique Française, T6 (1979), pp. 340-354

(p. 352)

CrossRef View Record in Scopus

Sauvet and Wlodarczyk, 1995 G. Sauvet, A. Wlodarczyk

Eléments d'une grammaire formelle dans l'art paléolithique

L'Anthropol. L. 99 (2-3) (1995), pp. 193-211

View Record in Scopus

Scubla, 2005a L. Scubla

"Ceci n'est pas un meurtre " ou comment le sacrifice contient la violence

F Héritier (Ed.), De la vialence II, Odile Jacob (2005), pp. 135-170 $350 \mathrm{pp}$.

Scubla, 2005b L. Scubla

Sacrifice et auto-domestication de l'homme

E. Pewzerer (Ed), Sacrifier: Se Sacrifier. Sens Éditions: Actes du Colloque d'Amiens (2005)

15-16 mars 2004. $198 \mathrm{pp}$.

Sereno et al., 2008 P.C. Sereno, E.A.A. Garcea, H. Jousse, C.M. Stojanowski, J.-F. Saliège

Lakeside cemeteries in the Sahara: 5000 years of holocene population and environmental changes

Plos One, 3 (8) (2008), p. e2995, 10.1371/journal.pone

0002995

CrossRef 
Tisseron, 2012 S. Tisseron

\section{Violence et agressivité. Une distinction essentielle}

Sante Ment, 165 (2012), pp. 6-7

\section{View Record in Scopus}

1 Original: "C'est en partant des rites qu'il faut chercher l'explication des légendes ».

Original: "Le mythe, marqué négativement par les tensions et contraintes qui l'engendrent, n'explique rien, ni lui-même, ni autre chose. II est ce qu'il faut expliquer. Au contraire, le rite, pratique positive, peut servir d'explication"».

Original: "le récit de la réduction d'une opposition, ou celui de la façon dont un manque, collectif dans le cas du mythe, individuel dans celui du conte, aura été comblé dans la mesure des forces humaines. "

4. Original: « restreint sans doute l'utilisation (du mythe et de ses diverses évocations) comme source documentaire. » 